\title{
A systematic revision of the family Harpetidae (Trilobita)
}

\author{
Malte C. Ebach ${ }^{1}$ and Kenneth J. McNamara ${ }^{2}$ \\ 'School of Botany, The University of Melbourne, Victoria 3010, Australia. \\ ${ }^{2}$ Department of Earth and Planetary Sciences, Western Australian Museum, \\ Francis Street, Perth, Western Austaralia, 6000, Australia.
}

\begin{abstract}
The systematics of the ten valid harpetid trilobite genera are reviewed. Seven are revised, using standard parsimony and three-item analysis. The monophyly of the Harpetidae is confirmed, and all ingroup genera can be defended as monophyletic groups except for the nonmonophyletic Scotoharpes group. Emended diagnoses are provided for all the genera within the family. The three subfamilies Dolichoharpinae, Eoharpetinae and Harpetinae are supressed within the Harpetidae. The genera Australoharpes and Sinoharpes are placed in synonymy with Dubhglasina. Thorslundops and Wegelinia are placed in synonymy with Hibbertia, and the subgenus Fritchaspis placed in synonymy with Lioharpes. Reticuloharpes and Helioharpes are placed in synonymy with Harpes. The Harpetidae, along with the Entomaspididae and Harpididae, is considered to belong in the Harpetida, which is herein raised to ordinal rank within the subclass Libristoma.
\end{abstract}

\section{INTRODUCTION}

The trilobite family Harpetidae Hawle and Corda, 1847 has been revised twice since its erection over 150 years ago, firstly by Whittington (1950a) and secondly by Pribyl and Vaněk (1986). Subsequently, numerous authors (Prantl and Pribyl, 1954, Vaněk, 1963, Pribyl and Vaněk, 1981, Pribyl and Vaněk, 1986) have left a legacy of what we regard as unnecessary subfamilies, poorly supported genera, subgenera, species and subspecies. The most recent revision by Pribyl and Vaněk (1986), perhaps the most detailed to date, indicates the enormity of the task involved in clearing up this 'Harpetid legacy'. For instance, one case relates to the subfamilies Dolichoharpetinae, Eoharpetinae and Harpetinae, which Pribyl and Vanék (1981) proposed. Each subfamily, however, is loosely supported by spurious characteristics that also define members of the other subfamilies. The Harpetidae should stand alone as a monophyletic group, or as several related clades supported by more than two or three synapomorphies each. Moreover, the past practice of assigning poorly preserved single specimens to new species and genera is unacceptable.

This is the first cladistic analysis undertaken of the Harpetidae. The result is that the Harpetidae are characterised by synapomorphies rather than by either ancestor-descendant or biostratigraphic relationships. Of the previously described genera, seven were subjected to a cladistic analysis of their internal relationships: Bohemoharpes Vaněk, 1963, Dubhglasina Lamont, 1948b, Eoharpes Raymond, 1905, Harpes Goldfuss, 1839, Hibbertia Jones and
Woodward, 1898, Lioharpes Whittington, 1950a and Scotoharpes Lamont, 1948a. Not included within this analysis were Brachyhipposiderus Jell, 1985 and Dolichoharpes Whittington, 1949, because each contain too few species to enable a cladistic analysis to be carried out. A cladistic analysis of Kielania Vaněk, 1963, along with a new genus, will be presented elsewhere (Ebach and McNamara, in prep.).

Three-item analysis is used as the favoured cladistic method (Williams and Siebert in Scotland and Pennington 2000). However, due to the implementation of the three-item method, standard parsimony is included for comparison. Because of the large degree of morphological variability encompassed by the species within each genus, any cladistic analysis dealing with supraspecific taxonomy must be treated with caution.

\section{METHODS}

In cladistics it is possible to construct cladograms using different methods. The most common method is standard parsimony analysis. The character-states in standard parsimony are treated as a transformation series, i.e., one state transforming into another. Although the use of transformation series has its merits, its premise of transformations is a pre-cladistic concept (Kitching et al. 1998). In order to move away from the 'established' standard parsimony analysis and into a realm in which character-states are treated as taxa (by degrees of relationship), three-item analysis is considered to be 
the most appropriate method to use. Three-item analysis finds a suite of the smallest units of relationship, a three-item statement, for each character (Nelson and Platnick 1991). A series of three-item statements is converted into a binary matrix and can then be processed using any standard parsimony program.

Three programs are necessary to implement a three-item analysis. MATRIX (Nelson and Ladiges 1995) converts the matrix into a threeitem matrix. TAX (Nelson and Ladiges 1995) then applies weights (factor $=50$ ) to each statement (see also Kitching et al. 1998). NONA 2.0 (Goloboff 1998) (max. trees $=100 ;$ mult $^{*}=1000$; trees per rep $=20$, TBR branch swapping), finds the most parsimonious trees. NONA excludes any ambiguous optimisations (i.e., ACCTRAN), and is the best mechanical way of finding the minimal tree (Williams 1996). Standard parsimony analyses are run using the same settings in NONA as in the three-item analysis and included for comparison.

Character states are optimised onto standard parsimony and three-item trees using WINCLADA version 0.9 (Nixon 1999). Characters optimised onto standard parsimony trees give inference to character transformations on the first tree. The first is chosen by default for each analysis. Optimised character states on three-item minimal trees provide no information regarding character transformations due to the nature of implementation (see Kitching et al. 1998: 167-186).

The characters coded for cladistic analysis were taken from both specimens and photographs. Specimens were painted with carbon, and then coated with ammonium chloride, in order to attain high quality, contrasting photographs.

\section{SYSTEMATIC PALAEONTOLOGY}

\section{Terminology}

Cephalic nomenclature used herein follows Whittington (1950a, fig 1, 1959, fig. 85, 1997). However, it should be noted that in Whittington (1959, fig. 85) there are two inaccuracies, arising from the redrawing of Whittington (1950a, fig.1). The line for the brim prolongation is too long, and points to the genal roll prolongation. The line for the genal roll prolongation is too short and points to the internal rim of the prolongation, rather than to the genal roll prolongation.

Due to the unique cephalic features of harpetids and the ambiguity of some of the terms, a revised version of cephalic features is given in Figure 1 herein. In this revision it is essential to introduce some new terms to cover morphological features that have not been previously named. These are:

- Girder kink - a sagittal deflection of the girder, resulting in either an anteriorly convex deflection, or a posteriorly convex deflection;

- Anterior boss - a sagittal inflation that may extend from the preglabellar field onto the genal roll, and sometimes onto the brim;

- Sagittal crest - a narrow ridge that extends sagittally along the glabella, and effaces posteriorly;

- Transverse preglabellar ridge - occurs as a raised, non-tuberculate region immediately anterior (sag.) to the preglabellar furrow, or as a ridge that is continuous with the eye ridge;

- Alar ridge - secondary furrow running parallel to axial and alar furrows, forming prominent ridge;

- Interalar furrow - an exsagittal furrow traversing the ala:

- Alar depression - a depressed area anterior to the ala, adaxial to axial furrow;

- Posterior alar depression - depressed area posterior to ala, proximal to posterior border.

\section{Function of the Harpetid Brim}

The harpetid brim has been described variously as functioning like a plough (Dollo 1909, Staff and Reck 1911), as a sieving or hydrostatic device (Rouault 1847, Richter 1920), or as a strengthening and lightening function (Miller 1972), or as a respiratory (Jell 1978) or sensory organ (Whittington 1950a). Despite the very variable interpretations, they do highlight the significance of the coarse pitting and/or caeca as being the primary functional organs of the fringe. With this assumption in mind, the presence of both pits and caeca on the brim indicate a functioning brim. Coarse pitting and caeca are herein regarded as being both a valid structure for cladistic analysis and as a possible 'functional organ'. Fine pitting or granules do not serve as homologous functional organs and are herein defined as 'ornament'.

\section{Material}

Figured specimens used in this study are held as follows: GLAHM, Hunterian Museum, Glasgow, U.K.; MBT, Museum of Natural History, Humbolt University, Berlin, Germany; Department of Palaeontology, Natural History Museum, London, U.K.; NIGP, Nanjing Institute of Geology and Palaeontology, Academia Sinica, Nanjing, China; NM, Department of Palaeontology, National Museum, Prague, Czech Republic; NMV, Department of Invertebrate Palaeontology, Museum Victoria, Melbourne, Australia; SM, Senckenberg Museum, Frankfurt, Germany; UUUG, Czech Geological Survey, Prague, Czech Republic; WAM, Department of Earth and Planetary Sciences, Western Australian Museum, Perth, Australia. 


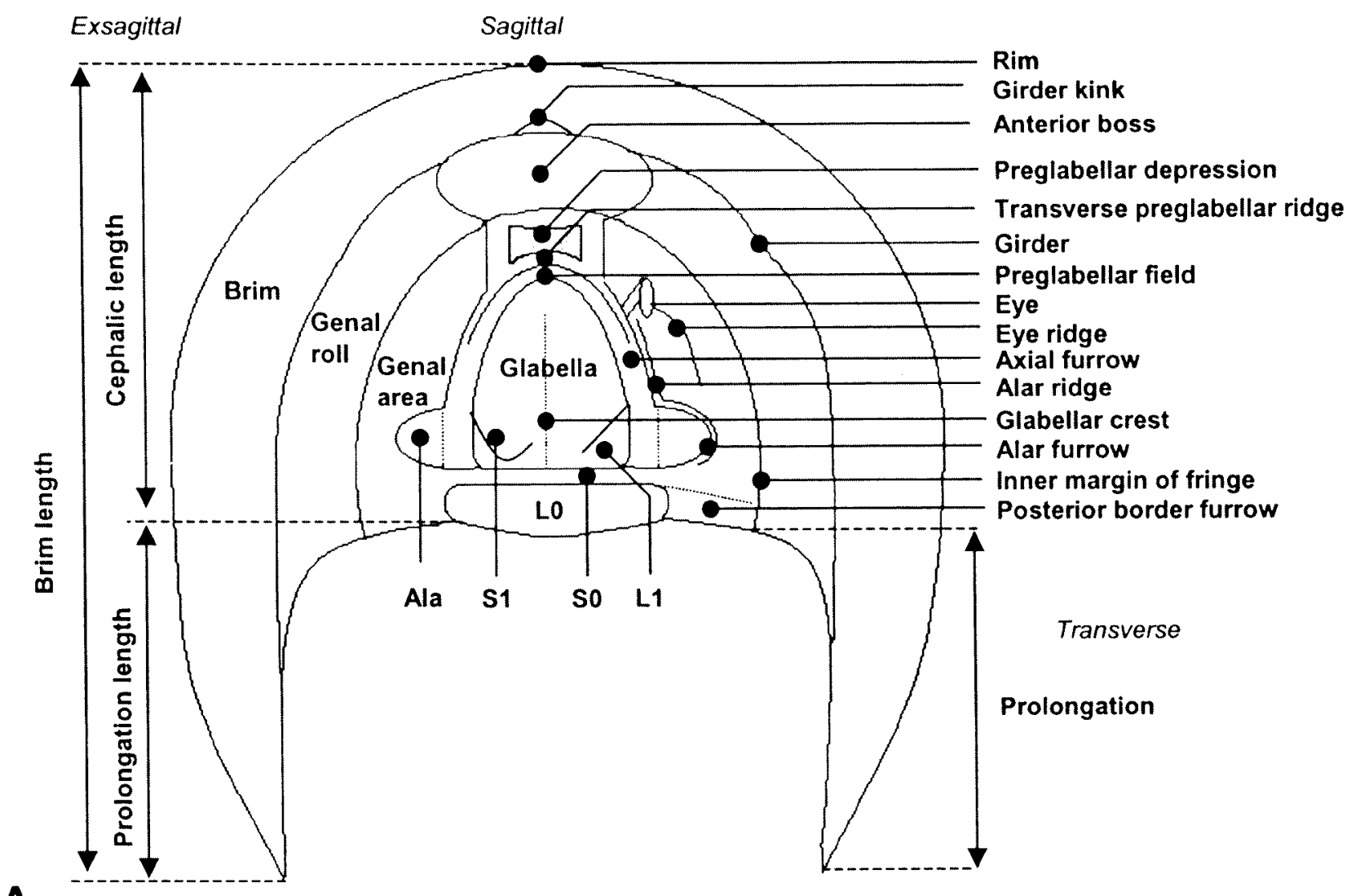

A

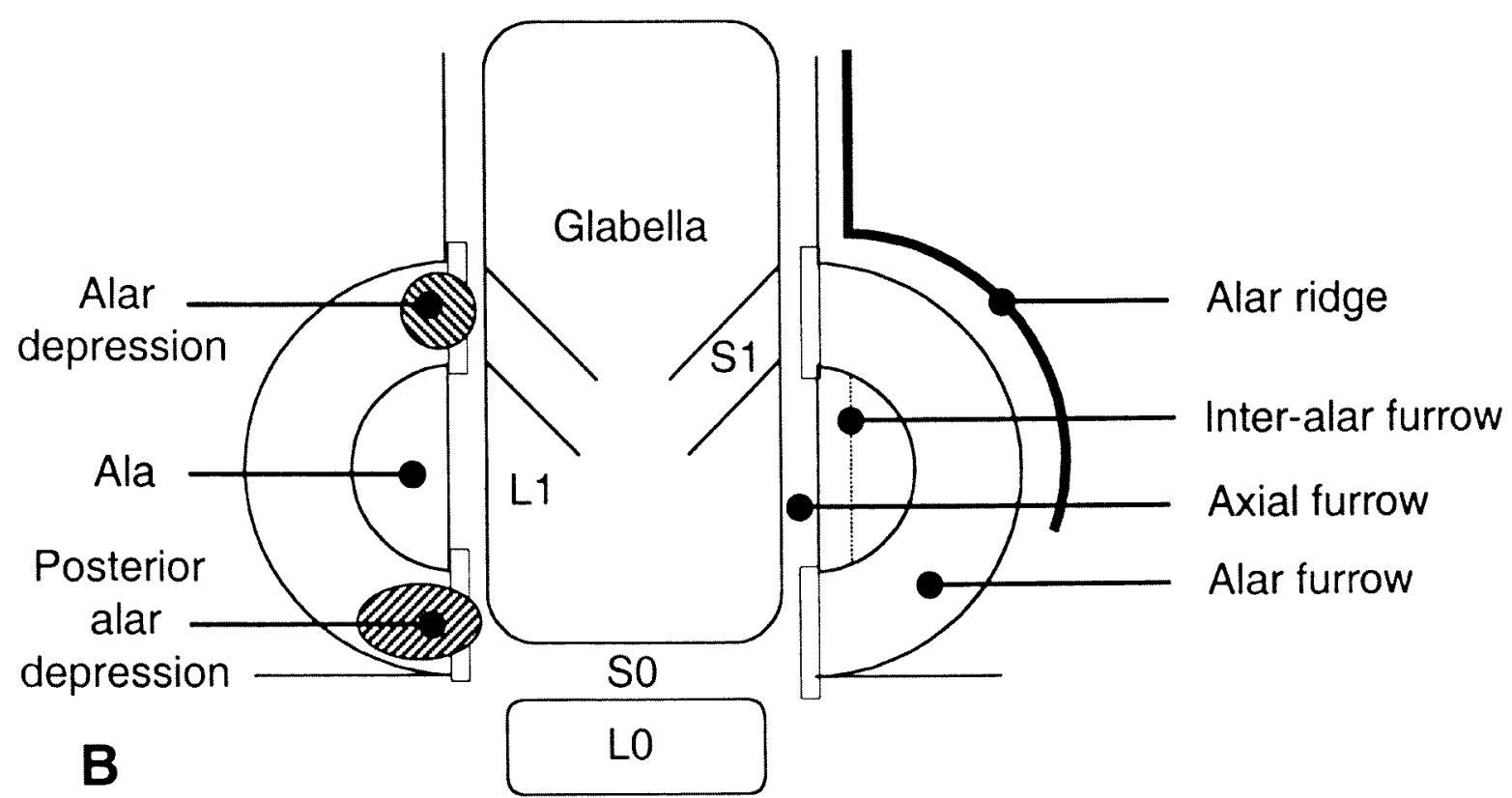

Figure 1 A, Schematic diagram of a harpetid cephalon. B, Nomenclature of the alae.

Class Trilobita Walch, 1771

Subclass Libristoma Fortey, 1990

Order Harpetida Whittington, 1959

Harpina Whittington, 1959: 415

\section{Emended Diagnosis}

Cephalon semicircular to ovate. Fringe inclined, consisting of vaulted inner genal roll, which is convex or flat, and an outer bilamellar brim, which is either flat, convex or concave; extends posteriorly to prolongation. Glabella anteriorly tapering, with 
one to three pairs of lateral glabellar furrows; preoccipital pair isolate triangular lateral lobes. Alae may be present. Genae convex; preglabellar field posterior to vaulted (in lateral view) genal roll. Prominent eye lobes or tubercles centrally located on genae, with well-defined eye ridges and in some forms with genal ridge. Suture marginal. No rostral plate. Radiating, anastomosing caecae may be present on genae, and preglabellar field, extending onto fringe prolongations. External surface of cephalon may be tuberculate or granulose. Thorax with 12 or more segments; pleurae flattened, with broad axial furrows. Pygidium elongate to short, subtriangular.

\section{Remarks}

Whittington (1959: O415) erected the Harpina as a suborder of the Ptychopariida Swinnerton, 1915 on the basis of the unique characteristics of the fringe and cranidium. While the semicircular to ovate, bilaminar fringe, with extensive pitting and caeca are indeed unique, they are, moreover, absent in all other suborders of the Ptychopariida. Fortey (1990) erected the Libristoma to act as a high level monophyletic group that equates with the Order Ptychopariida. The consequences are two-fold: either the Ptychopariida is renamed the Libristoma, or is proposed as a subclass consisting of all ptychopariid orders and suborders. The Libristoma is herein regarded as a subclass, as preferred by Fortey (1990: 558). The authors agree with Fortey (1990: 558) that the Subclass Libristoma will not upset current classification within the Ptychopariida and will need to be subjected to a cladistic analysis to assess monophyly of its orders. Fortey (1990), however, is sceptical that the subclass Libristoma will not be used as with many other higher-level taxonomic classifications in the past (see Stubblefield 1936, Harrington 1959, Bergström 1973 and Fortey and Owens 1975). Many higher-level taxonomic revisions are often ignored, but this should not stop the reform of redundant taxonomic groups.

Fortey (1990) kept the possibility of subclass Libristoma open and retained all orders and suborders in their traditional taxonomic rank. The adoption of Fortey's Libristoma, however, does have consequences on the taxonomic status of the Harpetida. Fortey and Chatterton (1988) and Fortey (1990) pointed out that two of the diagnostic characters of the Ptychopariida are the presence of a rostral plate and opisthoparian facial sutures. All members of the Harpetida lack a rostral plate and have a marginal facial suture. Consequently, the Harpetida is herein raised to ordinal status and is considered to be a monophyletic group within the Subclass Libristoma.

The Harpetida contains three families, the Harpetidae Hawle and Corda, 1847, Harpididae,
Whittington 1950a and Entomaspididae, Ulrich in Bridge 1930. This latter family Ludvigsen (1982) placed within the superfamily Solenopleuracea (see Fortey 1990: 562). However, Fortey (1990) has pointed out that there is no justification for retention of the superfamily Solenopleuracea.

The nomenclatural change from the Harpina Whittington, 1959 to the Harpetida is a result of the highlighting by Beu (1971: 56) of the homonymy between Harpidae Hawle and Corda, 1847 in the Trilobita and Harpidae in the Mollusca (see also Rheder 1972: 2; Chernohorsky 1972: 108; Rheder 1973: 3). The Harpetidae Hawle and Corda, 1847 and Harpididae Whittington, 1950a were placed on the Official List 'Names in Zoology' Opinion 1436 (1987: 137).

The Harpetida has an extensive evolutionary and geological history, spanning the Upper Cambrian to the Late Devonian (Frasnian). In the Early Ordovician, the ancestral Harpetidae lost the prominent ptychopariid-like sutures and gained the long prolongations typical of the Harpididae and Entomaspididae. However, the unique harpetid morphological characteristics and evolutionary history let them stand alone as a monophyletic group.

\section{Family Harpetidae Hawle and Corda, 1847}

Arraphidae Angelin, 1854: 21.

Harpidae Hawle and Corda, 1847; Beu 1971: 56; Rheder 1972: 2; Chernohorsky 1972: 108; Rheder 1973: 3; Prribyl and Vaněk 1986: 15; Opinion 1436 1987: 137.

\section{Emended Diagnosis}

Bilamellar fringe with opposed pits on outer surfaces. Genal roll steeply sloping; girder welldefined and may extend onto prolongation. Prolongation straight to incurving, of variable length. Alae semicircular adjacent to posterior glabellar lobes where present. When pits are present, concentrated on girder and rim. Hypostome pear-shaped in outline with ovate middle body, large anteriorly and small posteriorly. Thorax with 12-21 segments. Pygidium small, short (sag.), triangular, with few segments.

\section{Remarks}

Přibyl and Vaněk (1986) assigned the Harpetidae to the Conocoryphacea Angelin, 1854 due to a 'hypothetical congruent link' based on a high number of thoracic segments, small pygidium and the homologous shape of the hypostome, totally ignoring the presence of the fringe that only occurs within the Harpetidae. Pribyl and Vaněk's (1986) 'hypothetical' link is unsubstantiated and too unspecific to justify the synonymy. Herein the 
Harpetidae is considered to be a distinct, recognisable, monophyletic taxon that may share a close relationship, but is in no way grouped within the Conocoryphacea.

Whittington's (1959) emended diagnosis of the Harpetidae had been subsequently changed by Pribyl and Vanek (1981) who split the family into three subfamilies: the Dolichoharpetinae, Eoharpetinae and Harpetinae. Pribyl and Vaněk (1986: 22) established the Eoharpetinae for genera with semicircular or semi-elliptical, smooth, sometimes depressed alae below the level of genal lobes and eye ridges, and which do not show any 'close phylogenetic relationships to other Harpetid subfamilies'. A major problem with this grouping is that it is not based on any distinct characters. 'Semicircular' to 'semielliptical' or 'sometimes depressed ala' are vague, hard to define terms and occur in other genera (Dolichoharpes) that they did not place in the Eoharpetinae. Their claim that the Eoharpetinae shows no close phylogenetic relationships to other Harpetidae is a non sequiteur as they placed them in the same family. Another poorly described subfamily is the Dolichoharpinae Pribyl and Vanek, 1981: 191. This was based on the generic characters of its only included genus, Dolichoharpes. There seems little justification in this case to erect a subfamily on the basis of this single genus, especially given that this genus shares the diagnostic characters of the Eoharpetinae.

The third subfamily, the Harpetinae, was erected by Pribyl and Vanék (1981: 191) on the basis of a cephalon with brim horseshoe-like to pyriform in outline, depressed alae and concave brim (Pribyl and Vanék 1986: 15). Their diagnosis suffers similarly from descriptions of characters that are variable at species level, for instance, the Eoharpetinae, are defined on 'alae usually not depressed' and 'brim concave'. Both these characters are variable within several genera of the Harpetinae (Scotoharpes, Hibbertia and Bohemoharpes). The Dolichoharpetinae, Eoharpetinae and Harpetinae do not include whole genera, rather they represent characteristics that can be attributed to any number of taxa from a varying number of genera. All three subfamilies are considered non-monophyletic herein.

It should also be noted that recent reviews by Owen and Clarkson (1992) and Lespérance and Weissenberger (1998) place Platyharpes Whittington, $1950 \mathrm{~b}$ and Paraharpes Whittington, $1950 \mathrm{~b}$ in synonymy with Hibbertia Jones and Woodward, 1898.

\section{Genera Included}

Bohemoharpes Vanèk, 1963; Brachyhipposiderus Jell, 1985; Dolichoharpes Whittington, 1949; Dubhglasina Lamont, 1948a; Eoharpes Raymond, 1905; Harpes Goldfuss, 1839 [=Helioharpes Pribyl and Vaněk,
1981 and Reticuloharpes Vanèk, 1963]; Hibbertia Jones and Woodward, 1898 [=Metaharpes Lamont, 1948a, Platyharpes Whittington, 1950a and Paraharpes Whittington, 1950a, Harpesoides Koroleva, 1978]; Kielania Vanèk, 1963; Lioharpes Whittington, 1950a; Scotoharpes Lamont, 1948b; Thorslundops Pribyl and Vanèk, 1981; Wegelinia Pribyl and Vanèk, 1981.

\section{Genus Bohemoharpes Vaněk, 1963} Figure 2A

Bohemoharpes (Unguloharpes) Pribyl and Vaněk, 1981: 188.

Bohemoharpes (Declivoharpes) Prribyl and Vaněk, 1981: 188.

\section{Type Species}

Harpes naumanni Barrande, 1852 from the Silurian of Bohemia.

\section{Emended Diagnosis}

Oval or semicircular shaped brim; flat to concave, finely pitted with caeca; girder kink concave (sag.) in plan view. Glabella and genal area vaulted, S1 deep, L1 subtriangular; alae small and subdued; occipital ring with median tubercle. Thorax up to 26 segments, pleurae tapering laterally with wide interpleural furrow.

\section{Remarks}

The large number of subgenera proposed by Pribyl and Vanèk (1981) within the Harpetidae is unwarranted. Bohemoharpes (Declivoharpes) was erected on several trivial characters that include a "narrower (sag.) brim of horse-shoe shaped and smaller alae and a well perceptible pair of muscle scars near the preoccipital pair of axial furrows" (Pribyl and Vanék 1981: 188), that are missing in most species. Bohemoharpes (Unguloharpes) was also diagnosed using characteristics variable with the proposed subgenera, but contained within the genus. These include such characters as a "brim which is broad, almost flat, obliquely sloping forwards, by carinate glabella and relatively large alae." Neither of the above diagnoses are substantial enough to warrant a new subgenus, especially on characters such as muscle scars, that vary little between species and are only preserved in a handful of specimens. The subgenera Declivoharpes and Unguloharpes are not recognized herein.

Bohemoharpes was erected on the basis of the possession of a "distinctly concave brim". This single characteristic is absent in Harpes praecedens dvorcensis Prantl and Pribyl, 1954, which was subsequently placed in Bohemoharpes. This species has a raised and flat to convex brim. Harpes praecedens was later assigned to $B$. (Declivoharpes) by 

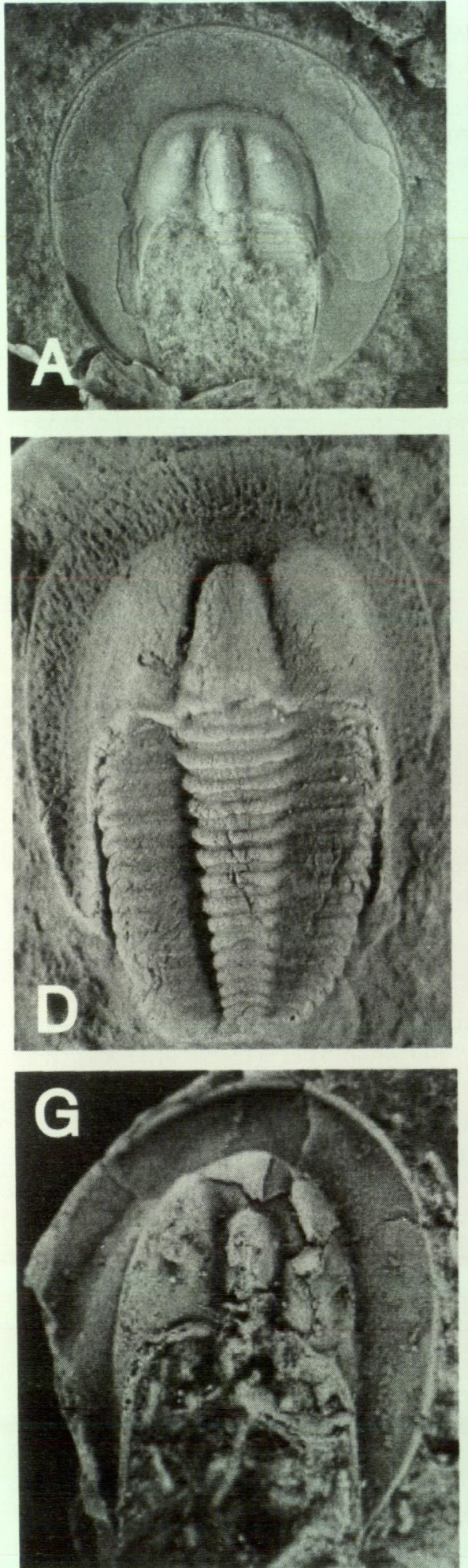
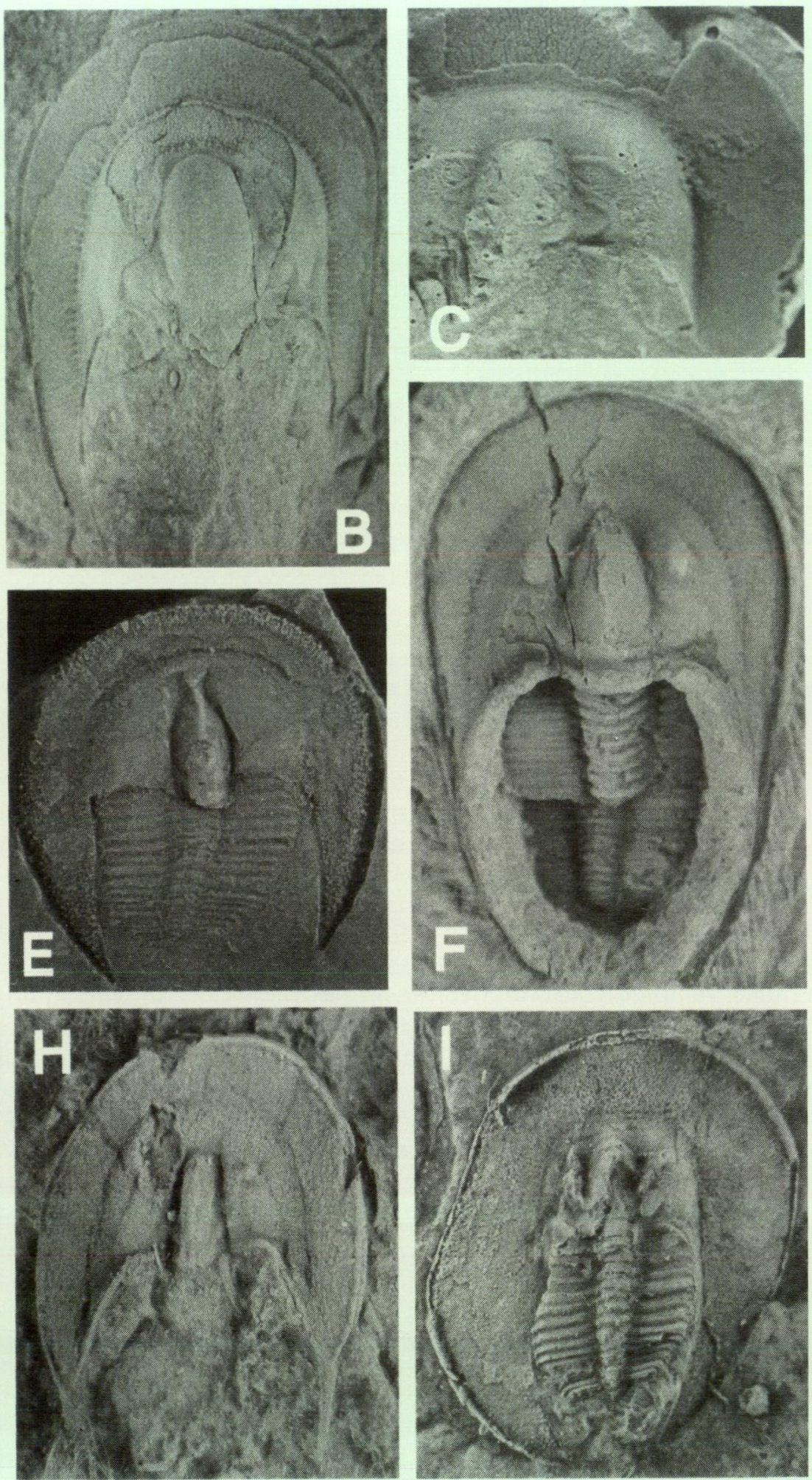

Figure 2 A, Bohemoharpes naumanni, external mould, dorsal view of cephalon NM L6127. B, Lioharpes venulosus, internal mould, dorsal view of cephalon NM L12547. C, Scotoharpes tatouyangensis, internal mould, dorsal view of cephalon NI 10131. D, Eoharpes primus, external mould, dorsal view of exoskeleton NM Coll. Kloucěk No. 48. E, Harpes radians, internal mould, dorsal view of cephalon, MBT 4512. F, Harpes perradiatus, external mould, dorsal view of exoskeleton, WAM 01.356. G, Scotoharpes singletoni, internal mould, dorsal view of cephalon, NMV P74430. H, Brachyhipposiderus secundus, internal mould, dorsal view of cephalon, holotype NIGP 108245. I, Hibbertia balclatchiensis, internal mould, dorsal view of cephalon IN 43838. 
Pribyl and Vanek (1986). However, the strongly raised and gently convex brim and the fineness of brim perforations are more characteristic of Kielania Vanék, 1963. Although Vanèk (1963) and Ormiston (1973) both mention steep genal prolongations as a unifying character of Kielania, the absence of preserved prolongations in $H$. praecedens does not mitigate against its inclusion within Kielania. Consequently, Bohemoharpes praecedens is herein assigned to Kielania.

\section{Species Included}

Harpes acuminatus Lindström, 1885; Bohemoharpes bubovicensis Pribyl and Vanék, 1986; H. buphthalmus Novák, 1890; H. gracilis Münster, 1840; B. hypsipyle Přibyl and Vaněk, 1986; B. inflexa Doubrava, 1991; B. janae Doubrava, 1991; H. naumanni Barrande, 1852; H. ovatus Bouček, 1935; H. ungula Sternberg, 1833; H. vittatus Barrande, 1852; H. wilkensii Münster, 1840.

\section{Bohemoharpes wilkensii (Münster, 1840)}

Harpes wilkensii Münster, 1840: 1.

Bohemoharpes wilkensii (Münster, 1840); Pruibyl and Vaněk 1986: 16, text-fig 8, figs 3-4.

Harpes crassifrons Barrande, 1846: 5; Prantl and Prribyl 1954, pl. 3, fig. 4, pl. 8, fig. 1.

Bohemoharpes crassifrons Vaněk, 1963: 227; Pribyl and Vaněk 1986: 16, text-fig 2, figs 1-2.

\section{Material}

Bohemoharpes wilkensii (holotype UUÚG JV 432) from the upper Silurian, Elbesreuth, Germany. Bohemoharpes crassifrons (holotype NM L 6128) from the Wenlock, Motol Member, Liten Formation, Kozel near Beroun, Bohemia, Czech Republic.

\section{Discussion}

Barrande (1846) erected Harpes crassifrons as a new species based on several incomplete specimens that share similar characteristics with Bohemoharpes wilkensii (Münster, 1840). The characters shared by both species include a strongly inflated genal roll, concave and perforated brim and ovoid fringe. Harpes crassifrons is herein considered a junior subjective synonym of $B$. wilkensii.

\section{Cladistic analysis}

\section{Outgroups}

Eoharpes was used as an appropriate outgroup for the Bohemoharpes analysis. The better known and preserved E. benignesis (Barrande, 1872) was used in place of the poorly preserved type species E. primus Raymond, 1905. The characters possessed by Eoharpes, such as the vaulted glabella and palpebral
Table 1 Data matrix for Bohemoharpes. '?' indicates missing data.

\begin{tabular}{lllllllllll}
\hline & 0 & $\mathbf{1}$ & 2 & 3 & $\mathbf{4}$ & 5 & 6 & 7 & 8 & 9 \\
\hline Eoharpes & 0 & 0 & 0 & 1 & 0 & 0 & 0 & 0 & 0 & $?$ \\
B. bubovicensis & $?$ & $?$ & $?$ & 0 & 1 & 0 & 1 & 1 & 0 & $?$ \\
B. buphthalmus & 0 & 0 & 1 & 1 & 0 & 1 & 1 & 0 & 1 & $?$ \\
B. hypsipyle & 0 & 1 & 1 & 1 & 0 & 0 & 0 & 0 & 0 & $?$ \\
B. inflexa & 0 & 0 & 1 & 1 & 1 & 1 & 1 & 0 & 0 & 1 \\
B. janae & 0 & 1 & 1 & 0 & 1 & 1 & 1 & 0 & 0 & 0 \\
B. naumanni & 1 & 0 & 0 & 0 & 1 & 1 & $?$ & 0 & 0 & 1 \\
B. ovatus & 0 & 1 & 1 & 1 & 1 & 0 & 1 & 0 & 0 & 1 \\
B. ungula & 0 & 1 & 1 & 2 & 1 & 0 & 1 & 0 & 0 & 0 \\
B. vittatus & 0 & 1 & 1 & 1 & 1 & 0 & 1 & 1 & 1 & 0 \\
B. wilkensii & 1 & 0 & 1 & 0 & 0 & $?$ & 1 & 0 & 1 & 1 \\
\hline
\end{tabular}

lobes, and small alae, are characteristic of the earliest known Bohemoharpes species including $B$. naumanni and $B$. wilkensii.

The following ten Bohemoharpes characters are listed as a data matrix in Table 1.

\section{Characters}

0. Brim shape. The Bohemoharpes brim falls in two broad categories, semicircular and circular.

0 : semicircular; 1 : circular

1. Brim concavity. Measured as the mid-brim concavity (sag.). The brim of Bohemoharpes is usually concave along the prolongation or lateral to the posterior border. Species with sagittal brim concavity tend to have overall brim concavity. Eoharpes has little sagittal concavity, thus state 0 is considered primitive.

0 : flat or convex; 1 : concave along whole margin

2. Girder kink. The kink is an independent character that is caused by either an increase in the anterior extent of the axial furrows and an increase in the size of the anterior boss, or an increase in genal roll convexity, as in B. wilkensii. The absence of the kink in Eoharpes is considered primitive.

0 : absent; 1 : present

3. Course of inner margin of fringe. The course of the inner margin of the fringe can be influenced by the presence of deep anteriorly extended axial furrows on the genal roll. Convexity (in dorsal view) is unusual and most inner margins are either straight or concave. Eoharpes codes as state 1.

0 : straight or convex 1: concave

4. Condition of preglabellar furrow (sag.). Preglabellar furrow length (sag.) is measured against axial furrow width (tr.). A long preglabellar furrow is usually shallow and at times limits the anterior extent of the axial furrows. Preglabellar length is measured sagittally directly anterior to the frontal 
lobe. Any wide (sag.) furrow anterolateral to the frontal lobe should be coded as state 0 .

0 : wide; 1 : narrow

5. Eye ridge. A distinct eye ridge is outlined by two furrows to form a raised ridge. Species that show only one furrow or a faintly inflated ridge should be coded as 1 .

0 : ridge present; 1 : faint inflation to absent

6. Shape of S1. Posterolaterally directed furrows are plesiomorphic to ' $\mathrm{J}$ ' shaped furrows. 'J' shaped furrows are not continuous with SO.

0 : posterolaterally directed; 1 : ' $\mathrm{J}$ ' shaped

7. Alar inflation. Alae are either flat or inflated. Alae are not inflated in Eoharpes, thus 7:0 is considered plesiomorphic.

0 : absent; 1 : present

8. Alar shape. Alae are either transversely or anterolaterally directed, long axis inclined at $45^{\circ}$ to a transverse line. Alar shape varies in most harpetid genera including Bohemoharpes. Alae are always transversely directed in Eoharpes.

0 : transversely directed; 1 : anterolaterally directed

9. Prolongation concavity: Measured as the outward concavity of the whole inner margin. All species of Bohemoharpes are concave at the anterior-most part of the inner margin of prolongation. A distinctly concave inner margin has the same concavity along the whole margin.

0 : straight; 1 : distinctly concave

\section{Results and Discussion}

Standard parsimony analysis yielded an unresolved consensus of 34 trees (length $=31$, ci 31, ri 35$)$. Three-item analysis yielded a minimal tree (length=4666, ci 73, ri 64) (Figure 3).

The cladistic analysis is consistent with the taxonomic synonymy of $B$. (Declivoharpes) and $B$. (Ungloharpes) into Bohemoharpes as there are no clades to justify such sub-divisions. The development of the ' $\mathrm{J}$ '-shaped, posterolaterally directed S1 [6: 1] appears to have occurred early in Bohemoharpes phylogeny. The other significant homologies that have resulted in two distinct groupings are the development of narrow preglabellar furrows [4: 1], absent in B. buphthalmus, $B$. wilkensii and B. hypsipyle, and alar inflation [7: 1] in B. bubovicensis and B. vittatus.

The Lochkovian Bohemoharpes hypsipyle, the youngest member of Bohemoharpes, is basal to all Silurian species. Bohemoharpes is monophyletic and consists of two distinct clades, $B$. buphthalmus, $B$. wilkensii and $B$. naumanni, $B$. inflexa, B. janae, B. ungula, B. ovatus, B. bubovicensis and $B$. vittatus.

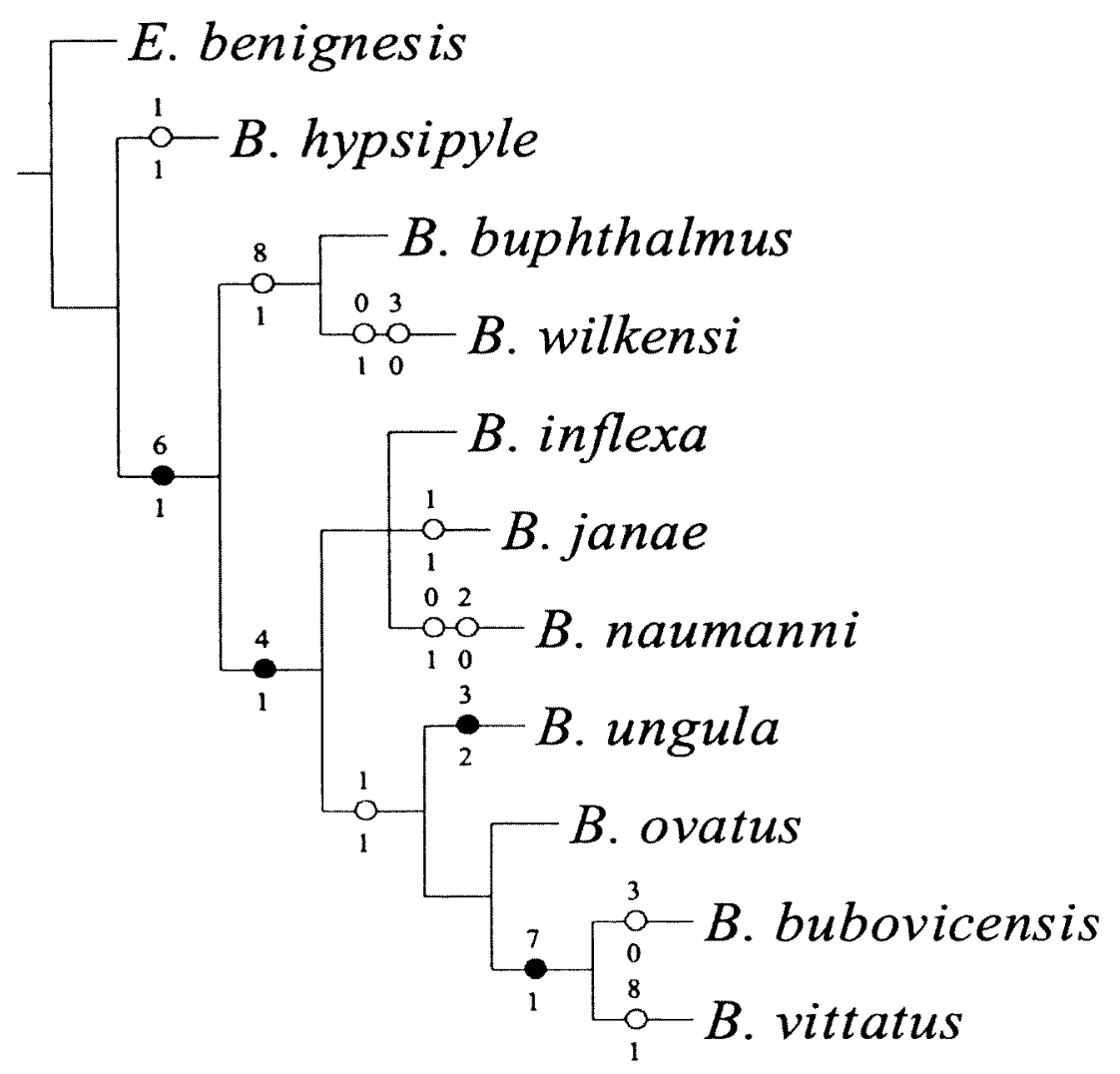

Figure 3 Three-item analysis of Bohemoharpes found a minimal tree of two trees (length $=4666$, ci 73, ri 64). 
Genus Brachyhipposiderus Jell, 1985 Figure $2 \mathrm{H}$

\section{Type Species}

Brachyhipposiderus logimus Jell, 1985, from the Lancefieldian (Tremadoc) Digger Island Formation, Waratah Bay, Victoria, Australia.

\section{Emended Diagnosis}

Cephalon semicircular; brim flat to concave; alae small, depressed; axial furrows deep; caeca radial, anastomising on genae and brim, interspersed with large pits; prolongations short, with well-defined spine.

\section{Remarks}

Brachyhipposiderus is the earliest known harpetid. It ranges from the Upper Cambrian-Lower Tremadoc Panjiazui Formation, Hunan Province, China to the Tremadoc Digger Island Formation, Victoria, Australia and Madaoyu Formation, Hunan Province, China.

Jell (1985: 71) described Entomaspis as 'giving rise to the harpetids' based on the "radial pitting of the brim, lower overall cranidial convexity, strongly developed girder, weakly developed alae, and glabellar and palpebral organisation of Brachyhipposiderus". However, one can argue that Harpides Beyrich, 1846 has equal ancestral claim, based on strongly anatomising caeca and weakly developed alae in Brachyhipposiderus.

A brief revision by Peng (1990: 110) considered Scotoharpes planilimbatus (Lu,1975) to be a member of Brachyhipposiderus. The wide, flat, heavily pitted brim, long prolongation spines and strong palpebral caeca are attributes common to both genera. However, because this species is only known from a brim, it is not possible to be certain that it has all the attributes of Brachyhipposiderus. Consequently, S. planilimbatus is retained in Scotoharpes.

\section{Species Included}

B. secundus Peng, 1990.

\section{Brachyhipposiderus secundus Peng, 1990}

Scotoharpes? hunanensis Peng, 1984: 380.

\section{Material}

NIGP 108250 figured in Peng (1984, pl. 17, figs 1, 2). NIGP 108245-9 figured in Peng (1990, pl. 20, figs 1-5).

\footnotetext{
Discussion

Brachyhipposiderus hunanensis was described from a "single poorly preserved internal mould of cephalon" (Peng 1990: 109). This specimen was
}

initially placed in Scotoharpes, however, the "short transverse triangular-shaped prolongation, the sturdy genal spine and strong girder" (Peng 1990: 109) suggest that it belongs in Brachyhipposiderus. The incomplete cephalon of the type specimen and the narrow brim, wide cephalon and small size of the specimen figured in Peng (1990, pl. 20, fig 6), indicate that it is a juvenile specimen, possibly of $B$. secundus. Peng (1990), however, believed B secundus to be "morphologically different" based on "proportionally longer prolongations [and] more posteriorly placed girder [that] meets the internal rim more anteriorly to the tip of the prolongation" (Peng 1990: 110). The morphological difference between both species is based on slight variation in the girder and prolongation. The difference in age is used to define species as $B$. secundus is "stratigraphically younger than the earlier $B$. hunanensis" (Peng 1990: 110). However, differences in age or biogeography are not valid characters to use in the characterisation of a species. Consequently, $B$. hunanensis is considered to be a junior subjective synonym of $B$. secundus.

\section{Genus Dolichoharpes Whittington, 1949}

\section{Type Species}

Eoharpes uniseralis Raymond, 1925.

\section{Emended Diagnosis}

Cephalon ovate, strongly convex, with short median and anterior lateral glabellar furrows; alae large and deeply depessed below rest of genae; girder extending to tips of very long prolongations; brim narrow; coarse reticulate ornament on fringe and genae; glabellar lobes large, with curved ridge.

\section{Remarks}

Dolichoharpes is the most distinctive harpetid genus, and yet it is the hardest to distinguish at species level. Since Whittington's (1949) erection of the genus, doubt over the establishment of several new species was expressed by DeMott (1963) and Shaw (1968) (see Chatterton and Ludvigsen 1976). DeMott (1963) synonymized three species (Dolichoharpes escanabe (Hall, 1851), D. dentoni (Billings, 1863), D. rutrellum (Clarke, 1897)) with D. uniseralis, and Shaw (1968) synonymized $D$. proclivius Esker, 1964 and $D$. arcticus Whittington, 1954 with $D$. reticulata Whittington, 1949. The remaining species, $D$. doranni Whittington, 1950a and $D$. villosus Koroleva, 1978 are based on fragmentary specimens, too poor to use for cladistic analysis. In the discussion on $D$. aff. reticulata, Chatterton and Ludvigsen (1976: 43) noted that the characters used to separate North American species were variable, a problem that is common to all species 
of Dolichoharpes. The single incomplete internal mould of Dolichoharpes villosus from the Ordovician of North Kazakhstan (Korovela 1978), is distinguished by indeterminate characters. These include 'basal furrows on the glabella', gently sloping anterior region and narrow convex glabellar lobes (Koroleva 1978: 219). The characters distinguishing $D$. villosus are found in most Dolichoharpes specimens from North America (Chatterton and Ludvigsen 1976; Shaw 1968).

More specimens of Dolichoharpes need to be found before a thorough taxonomic and cladistic study of Dolichoharpes can be made. This reiterates the sentiment already voiced by Whittington (1950a: 30) and Chatterton and Ludvigsen (1976).

\section{Species Included}

Dolichoharpes doranni Whittington, 1950a; $D$. reticulata Whittington, 1949; D. villosus Koroleva, 1978; D. sp. Chatterton and Ludvigsen 1978); D. sp. (Shaw 1968); D. sp. (Dean 1979); D. sp. (Přibyl and Vaněk 1981).

\section{Cladistic Analysis}

\section{Outgroups}

There are no known harpetid genera that exhibit the unique features of the cephalon and extremely long prolongations of Dolichoharpes. The mid Ordovician genus is contemporary with most Ordovician harpetid genera, such as Scotoharpes, Eoharpes and Hibbertia. However, Eoharpes and Brachyhipposiderus are potential outgroups for a future cladistics analysis. Their characters, such as the narrow brim in Brachyhipposiderus and the development of prolongations and ornament in Eoharpes, are possibly plesiomorphic.

\section{Characters}

Whittington (1949: 281) noted the character that best distinguished $D$. reticulata from $D$. uniseralis was the detail of the fringe. Even in the complete silicified specimens of $D$. aff. reticulata described by Chatterton and Ludvigsen (1976), the fringes themselves exhibit little detail of the girder or inner margin due to coarse pitting.

Whittington (1950a), however, suggested that $D$. doranni is closely related to the North American species because it does not possess "the ridge crossing the first glabellar lobes or the less strongly ornamented oval areas of the second lobes." (Whittington 1950a: 29-30). This is perhaps the only suggestion possible given the poor detail in the majority of specimens.

\section{Genus Dubhglasina Lamont, 1948b}

Figure 4

Australoharpes Harrington and Leanza, 1957: 195.
Sinoharpes Sheng, 1974: 105; Tripp et al. 1989: 47.

\section{Type Species}

Harpes parvula $\mathrm{M}^{\prime} \mathrm{Coy}, 1851$ : 387 , from the Caradoc (Middle Ordovician) Didymograptus superstes Mudstones, near Girvan, Ayrshire, Scotland.

\section{Emended Diagnosis}

Cephalon oval in outline, low in convexity. Girder extending to tip of prolongations; genal roll narrow; brim broad and flattened. Small posterior lateral glabellar lobes. Preglabellar furrow and preglabellar field elevated, laterally outlined by furrows which diverge forward. Alae faint. Pits small; genal caeaca absent.

\section{Remarks}

Tripp et al. (1989) favoured the possible synonymy of Sinoharpes with Dubhglasina based on the weak development of the alae and short prolongations. Lamont's (1948b) Dubhglasina aldonsensis was based on a single broken, albeit well-preserved, internal mould (Figure 4 herein), referred to as "this unique and beautiful specimen" by Tripp (1976: 392). Sinoharpes is based on several incomplete specimens. However, both genera retain sufficient morphological features to show similarities with all species that have been referred to the Ordovician genus Australoharpes. The elongate glabella, wide (tr.) axial furrows, wide and flat brim, and elongate cephalon shape distinguishable in Dubhglasina and Sinoharpes, are present in Australoharpes. Sinoharpes does share two common characteristics with Dubhglasina, which are not present in the described species of Australoharpes: the uneven brim length, presence of caeca and relatively deep S1. However, these attributes do not justify the generic separation of these forms from Australoharpes.

Lamont (1948b) distinguished Dubhglasina from Scotoharpes "by absence of deep furrow between outer and inner parts of cheeks in front of glabella, by poorer development of alae and by absence thereon of bifurcating suture lines; also by absence of "genal caecum" running postero-laterally from eye". As these features are present in species of Australoharpes, and given that the name Dubhglasina was erected prior to Australoharpes, then Australoharpes, like Sinoharpes, is herein regarded as a subjective synonym of Dubhglasina. This extends the geographic range of Dubhglasina to Australia, South America and China and the stratigraphic range from the Lower Caradocian to the early Ashgill (Upper Ordovician).

\section{Species Included}

Australoharpes depressus Harrington and Leanza, 
1957; A. expansus Jell, 1985b; A. pospelovi Petrunina, 1966; A. precordilleranus Baldis and Gonzalez, 1986; A. singletoni Jell, 1985b; Sinoharpes yunnanensis Sheng, 1974.

\section{Dubhglasina paroula (M'Coy, 1851)} Figure 4

Harpes? parvulus M'Coy, 1851: 387; M'Coy 1852: 337, 374, pl. 1L, fig. 3; Whittington 1950a: 55; Morris 1988: 104 .

Dubhglasina aldonsensis Lamont, 1948b: 533; Tripp 1976: 391-392; Přibyl and Vaněk 1986: 17.

Dubhglasina paroula (M'Coy, 1851); Owen et al. 1996: 136, 140, fig. 3C; Armstrong et al. 2000: 36.

\section{Remarks}

M'Coy (1851) described Harpes? parvulus from early Caradoc clasts in the Late Ordovician Wrae Limestone near Peebles, Scotland. Owen et al. (1996) have pointed out that this form is very similar to Dubhglasina aldonsenis, the only differences being the complete absence of alae (they are said to be 'just discernable' in D. aldonsensis (Owen et al. 1996: 140 ) and a 'slightly shorter (sag.) brim which has a more transverse posterior edge mesially' in $H$ ? parvulus. The cladistic analysis (Figure 5; Table 2) codes $A$. aldonsensis and $A$. parvula identically. The small 'just discernible' alae in $A$. aldonsensis is perhaps the only feature that would separate the specimens from Aldons Old Quarry Girvan from the single specimen of $A$. parvula from the Wrae Limestone of the same age. A slight difference that

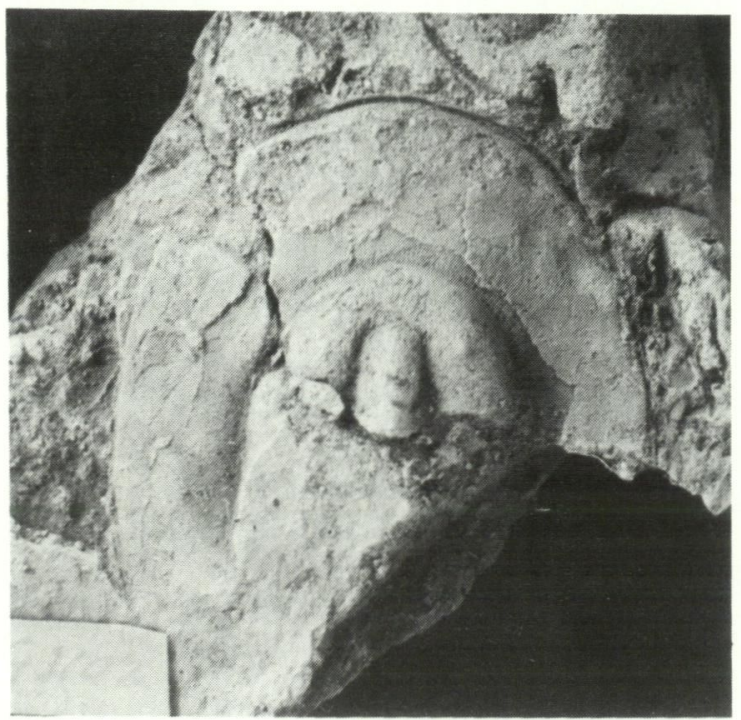

Figure 4 Dubhglasina parvula ( $\left.\mathrm{M}^{\prime} \mathrm{Coy}, 1851\right)$. The holotype of Dubhglasina alsonsensis Lamont 1948b, holotype, GLA HMA5193 from the ?Middle Ordovician Didymograptus superstes Mudstones, Aldons Old Quarry, near Girvan, Ayrshire, Scotland, x3.5. exists in the transverse posterior margin is not sufficient justification to separate the two species. Moreover the question of whether or not alae are truly absent in the poorly preserved single specimen of $A$. parvula is debatable (Owen et al. 1996: 137, fig 3C). Following Owen et al. 1996, it is considered herein that Harpes? parvula belongs in Dubhglasina. Consequently, Dubhglasina aldonsensis is herein considered to be a junior subjective synonym of Dubhglasina parvula.

\section{Cladistic analysis}

\section{Outgroups}

The type species of Brachyhipposiderus and Eoharpes were used as outgroups for Dubhglasina. Brachyhipposiderus and Eoharpes share some similar morphological characteristics with Dubhglasina, such as short prolongations and a vaulted glabella and palpebral field. The data matrix with codings for all eight species is given in Table 2 .

\section{Characters}

0. Brim length (sag. vs. exsag.). Brim length determines the shape of the whole cephalon. State 0 indicates a 'square' shaped brim common in the outgroup as opposed to an elongate shaped brim dominant in Dubhglasina.

0 : square shaped; 1 : elongate

1. Brim length versus glabella length (sag). The size of the glabella may vary in proportion to the brim sagittally. State 0 indicates a short brim, common in Brachyhipposiderus and Eoharpes and in the Harpididae. Dubhglasina usually has an equal to long brim.

0: short; 1: equal; 2: long

2. Girder kink: Measured as a slight convex 'kink' sagittally, in front of the preglabellar furrow. The ' $k$ ink' is best seen in undistorted specimens. The convex girder is absent in both outgroups.

0 : absent; 1 : present

Table 2 Data matrix for Dubhglasina. '?' indicates missing data.

\begin{tabular}{llllllllll}
\hline & 0 & $\mathbf{1}$ & $\mathbf{2}$ & $\mathbf{3}$ & $\mathbf{4}$ & $\mathbf{5}$ & $\mathbf{6}$ & $\mathbf{7}$ & $\mathbf{8}$ \\
\hline Brachyhipposiderus & 0 & 0 & 0 & 0 & 0 & 1 & 0 & 0 & 1 \\
Eoharpes & 0 & 0 & 0 & 0 & 0 & 0 & 0 & 0 & 0 \\
D. aldonsensis & 1 & 1 & 0 & 0 & 0 & 1 & 0 & $?$ & $?$ \\
D. depressus & 1 & 1 & 1 & 1 & 1 & 1 & 0 & 0 & $?$ \\
D. expansus & 1 & 1 & 1 & 1 & 0 & 1 & 1 & 1 & 0 \\
D. parvula & 1 & 1 & 0 & 0 & 0 & 1 & $?$ & $?$ & $?$ \\
D. singletoni & 0 & 0 & 1 & 1 & 0 & 0 & 1 & 1 & 1 \\
D. yunnanensis & 1 & 1 & 0 & 0 & 0 & 1 & 1 & 0 & $?$ \\
\hline
\end{tabular}


3. Condition of anterior boss. The earliest known appearance of the anterior boss occurs in Dubhglasina. A large predominant (bulbous) boss may expand onto the brim and reach as far as the anterior border. The anterior boss develops from the inflation of the area between two anteriorly extended axial furrows. At times only a slight inflation occurs between the extended axial furrows. The anterior boss is absent in both outgroups.

0 : absent; 1 : axial furrows; 2 : bulbous

4. Position of eye. Measured as the anterior or posterior (exsag.) position of the midlength of the eye in relation to the preglabellar field. State 1 is only known in $D$. depressus, in which the eyes are clearly anteriorly positioned in relation to the preglabellar field. The presence of the posteriorly positioned eye is common in later harpetids, however its occurrence in Dubhglasina may indicate a derived character.

0 : posterolateral; 1 : anterolateral

5. Condition of eye ridge. The eye ridge exists between the frontal lobe of the glabella and the eye. The ridge can either be transversely or posterotranversely directed adaxially from the glabella. The eye ridge is present in Brachyhipposiderus and absent in Eoharpes.

0 : absent; 1 : present

6. Posterior extent of girder. The girder forms a ridge that is separate from posterior border and is raised as far as the prolongation tip or spine. A posteriorly extended girder is absent in both outgroups.

0 : absent; 1 : present

7. Convexity of the brim. Brim convexity varies greatly in Dubhglasina. The brim is strongly convex in $D$. singletoni and brim convexity is absent in $D$. depressus. Convexity is not due to short prolongations and a vaulted palpebral field, as the brim is flat or even slightly convex in Eoharpes. A convex brim is present in all species of Brachyhipposiderus.

0 : flat; 1 : convex

8. Presence of spine prolongation. The only known occurrence of a spine prolongation in Dubhglasina is in $D$. singletoni. Other species of Dubhglasina may possess one. However, it is an unusual character in the Harpetidae, with the exception of Brachyhipposiderus. Spines are common in the Entomaspididae, and are herein considered plesiomorphic. Spines are absent in Eoharpes.

0 : absent; 1 : present

\section{Results and Discussion}

Standard parsimony analysis yielded a single parsimonious tree (length $=14$; ci 64; ri 61) (Figure

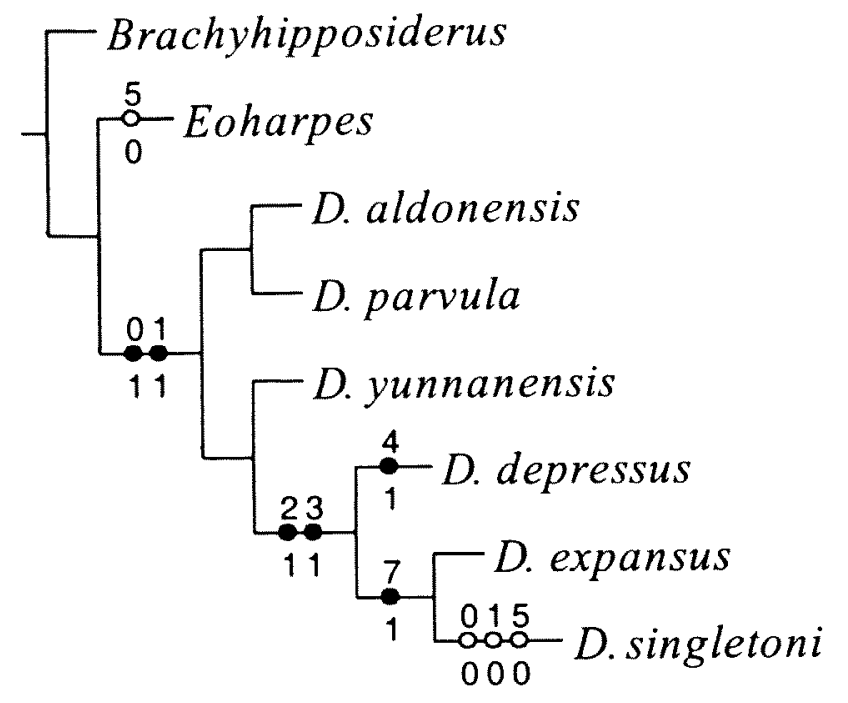

Figure 5 Standard parsimony analysis of Dubhglasina yielded a single most parsimonious tree (length $=14$; ci 64 ; ri 61).

5). Three-item analysis, however, found 13 trees (length $=36$; ci 69; ri 56) that formed an unresolved consensus. In the three-item cladogram $D$. yunnanensis and $D$. paroula together form a sister clade to $D$. depressus, $D$. expansus and $D$. singletoni, providing no overwhelming support for or against the synonymy of Australoharpes into Dubhglasina. The clade comprising $D$. depressus, $D$. expansus and $D$. singletoni is supported by the presence of long prolongations and a girder kink. These unique synapomorphies, however, are only present in standard parsimony analysis. The characters 'long prolongations' [8:1] and a 'girder kink' [2:1] are informative, however, they are not paramount in supporting the poorly preserved species of Dubhglasina that have their prolongations missing. Differences in standard parsimony and three-item analysis are difficult to assess in the Dubhglasina analyses due to the lack of resolution in the threeitem minimal tree.

\section{Genus Eoharpes Raymond, 1905 Figure 2D}

\section{Type Species}

Harpes primus Barrande, 1872 from the Sárkian (Lower Ordovician) of Bohemia.

\section{Emended Diagnosis}

Cephalon semicircular, with flat brim; fringe slightly inclined anteriorly and heavily pitted with varying degrees of caeca and pitting on genal area. Genal roll steeply inclined to concave and pitted. Glabella gently convex, elongate to triangular; highest point at midline on occipital ring; L1 small, S1 posterolaterally directed, effacing adaxially. Eyes 
present with eye ridge, extending to axial furrow. Alae small and depressed. Girder extending to rounded prolongation tip; prolongations short; inner margin gently concave, external rim posteriorly directed. Hypostome pear-shaped. Thorax oval, varying between twelve to fifteen segments. Small pygidium with three segments.

\section{Remarks}

Novák (1885) assigned Harpes benignensis Barrande, 1872 and Harpes primus Barrande, 1872 to Harpina Novák, 1884. However, the name Harpina was already preoccuppied. Thus Raymond (1905) introduced the name Eoharpes into which the two Barrande species were placed. Further confusion of the generic attributes of Eoharpes persisted (see Sinclair (1947) and Whittington (1950a)). Harpina rutrelium Clarke, 1897 and Harpina minnesotensis Clarke, 1897, both have features characteristic of Dolichoharpes, even though the latter has been referred to Eoharpes by Pribyl and Vaněk (1986).

Eoharpes primus herschenesis (Koch and Lemke, 1996: 34, pl. 1, fig. 1) from the Ordovician of Germany, is only represented by one poorly preserved specimen. The assignment of a subspecies is not justified, with minor differences such as varying number of pits on brim and genal roll, being likely due to intraspecific variation.

\section{Species Included}

Harpes benignensis Barrande, 1872; E. cristatus Romano, 1975; E. guichenensis Henry and Phillipot, 1968; E. macaoensis Romano and Henry, 1982.

\section{Cladistic Analysis}

Outgroups

Eoharpes and Brachyhipposiderus are two of the earliest known genera of harpetids. Each genus consists of primitive harpetid characteristics, such as small or absent alae, short (sag.) glabella, the presence of spines on Brachyhipposiderus and small subdued eyes on Eoharpes. Both genera do possess some apomorphic characteristics, such as absence of caecae that are common in more derived genera such as Kielania. Harpides has been selected as the outgroup for the Eoharpes analysis based on the aforementioned characteristics that are primitive in the Harpetidae. Rather than using the type species Harpides hospes Beyrich, 1846, $H$. atlanticus Billings, 1865 is coded herein, due to its excellent preservation. Coding for all character states are listed in Table 3.

\section{Characters}

0 . Anterior preglabellar depression. The character can also be interpreted as the 'sagittal lengthening of the preglabellar furrow'. The anterior depression should not be confused with the steep and
Table 3 Data matrix of Eoharpes. '?' indicates missing data.

$\begin{array}{llllll}0 & 1 & 2 & 3 & 4 & 5\end{array}$

$\begin{array}{lllllll}\text { Harpides } & 0 & 0 & 0 & 0 & 0 & 0 \\ \text { E. benignensis } & 1 & 1 & 1 & 1 & 0 & 0 \\ \text { E. cristatus } & 1 & 0 & 0 & 0 & 1 & 1 \\ \text { E. guichenensis } & 1 & 1 & 1 & 1 & 0 & 0 \\ \text { E. macaoensis } & 0 & 0 & 0 & 0 & 1 & 1 \\ \text { E. primus } & ? & 1 & 0 & 1 & 0 & 0\end{array}$

sometimes concave genal roll common to all known species of Eoharpes. The depression extends from the preglabellar furrow (sag.) and effaces posterior to the genal roll. An anterior preglabellar depression is absent in the outgroup.

0 : absent; 1 : present

1. Condition of eye ridge. The presence of an eye ridge is autapomorphic to all known species of Eoharpes. However, the ridge is diffuse in some species and distinct in others. The character is not dependent on the amount of ornament on the genal area. A diffuse eye ridge is possibly derived from a prominent ridge present in the outgroup.

0 : prominent; 1 : diffuse

2. Glabella shape. Two distinct glabella types exist in Eoharpes, the more common and plesiomorphic is an elongate shape present in the outgroup, and the derived type is triangular in shape, as displayed in E. benigenesis and E. guichenensis.

0 : elongate; 1 : triangular

3. Inner fringe convexity. Measured as the height between the posterior border (exsag.) and the inner margin of the fringe (exsag.) in lateral view. An inflated genal area is higher than the posterior border. The outgroup lacks genal inflation and is herein considered plesiomorphic.

0 : absent; 1 : present

4. Condition of axial furrow posteriorly. The posteriormost part of the axial furrow opposite L1 effaces in several species of Eoharpes. The absence of the lateral furrow does not affect L1 size or shape. The outgroup does not display this state.

0 : absent; 1 : present

5. Alar size versus L1 size: Alar size is best measured against $\mathrm{L} 1$ as both structures are adjacent and may vary allometrically during ontogeny. Although no ontogenetic material of Eoharpes exists, comparable evidence can be drawn from Dolichoharpes. The outgroup Harpides and other harpidids and entomaspidids do not have developed alae. Thus small alae are herein considered plesiomorphic in Eoharpes. 


\section{Results and Discussion}

The same single parsimonious cladogram was yielded by both standard parsimony (length $=7$, ci 85 , ri 87) and three-item analysis (length $=14$, ci 85 , ri 83) (Figure 6). Eoharpes cristatus and E. macaoensis form a clade supported by the presence of an inner marginal fringe and a posteriorly effaced axial furrow. Sisters to these are remaining Eoharpes species, distinguished by the presence of an anterior preglabellar depression and triangular glabella. $E$. benignesis and $E$. guichenensis are distinguished by the presence of a diffuse eye ridge. The results in the Eoharpes analysis are similar to those presented in the Dubhglasina discussion. Both genera contain two clades each that are supported by two character-states. These character-states do not represent a separate monophyletic grouping that would justify a new taxonomic group in either genus.

The monophyly of Eoharpes is not clear as there are no basal characters supporting the genus in either analysis. This is due to the small number of characters used in the analysis. The cladistic analysis of Eoharpes, however, is beneficial because it finds the relationships within the highly stratigraphically constrained group. All species occur within the Llanvirn-Llandelio (Middle Ordovician), with the exception of the poorly known E. macaoensis, which has a possible lower Caradoc? range (Romano and Henry 1982).

The close similarities between E. primus, $E$. benignensis and E. guichenensis were noted previously by Chavel and Henry (1966), Henry and Phillipot (1968) and Romano and Henry (1982), as similar characters within the cladistic analysis [1:1], [2: 1] and [3: 1].

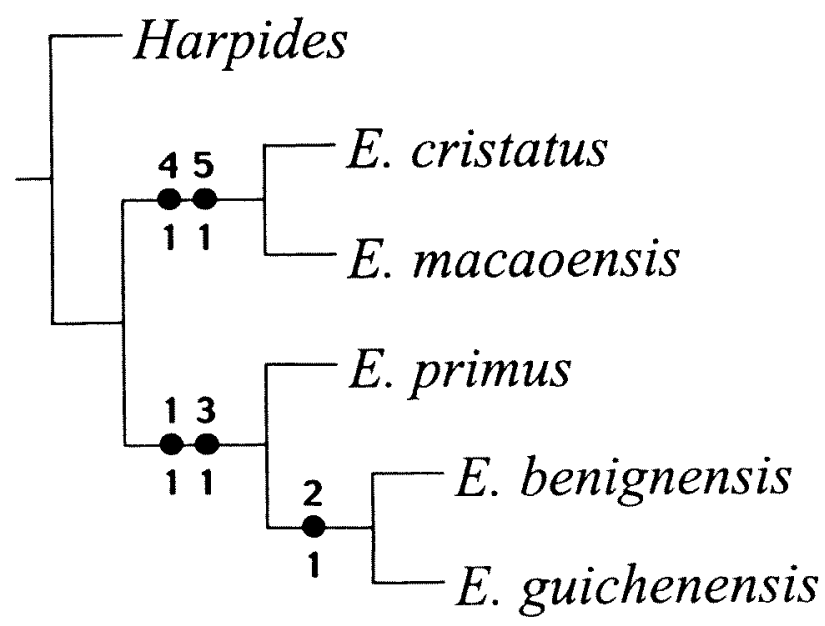

Figure 6 Standard parsimony and three-item analysis of Eoharpes yielded a single cladogram.

\section{Genus Harpes Goldfuss, 1839}

Figure 2E, F

Reticuloharpes Vaněk, 1963: 229.

Helioharpes Pribyl and Vaněk, 1981: 188-9.

\section{Type Species}

Harpes macrocephalus Goldfuss, 1839, Eifelian (Middle Devonian), Germany.

\section{Emended Diagnosis}

Cephalon semicircular to ovate. Brim flat, pitted, rim wide and raised along whole margin. Glabella elongate to sub-triangular, inflated and tuberculate. Genal roll long (sag.), convex and vaulted. Eyes set adaxially and anterior to preglabellar furrow; eye ridges weak. Alae transversely elongate, larger than L1. Thorax up to 29 segments.

\section{Remarks}

The type species of Reticuloharpes, $R$. reticulatus, was figured by Vanek (1963: 228, fig. 4). The drawing, however, has several flaws. The elongate prolongations are illustrated as being longer than the cephalic length (sag.) (see characters 17 and 18 below). They are also depicted as curving adaxially to form an inwardly concave section at the base of the prolongation. Neither of these characters are present in actual specimens of Reticuloharpes. When measured, the prolongations are always shorter than the whole cephalic length, not longer as illustrated by Vaněk (1963: 229, fig. 4). The concave margin also does not exist on any known species of harpetid. The inward concavity is an optical illusion or 'space curve' that forms when the prolongations (that are inverted perpendicularly to the brim) are seen stereoscopically. A photograph does not capture a space curve, thus the inward concavity is absent.

Other diagnostic features of Reticuloharpes including a vaulted glabella 'narrowing towards the frontal part, with a median elevation' (Vanèk 1963: 229), are characteristic of all Harpes, Reticuloharpes and Helioharpes species. Vaněk (1963) noted that "the nearest genus may be Harpes", however it differs by the "finer brim perforation and...single row of distinct perforations at the external rim" and the shape and size of the eye ridges. These characters distinguish the characteristics (homologues) that are variable between different species of the same genus rather than the taxonomic variations between two different genera.

A similar criticism can be made of Helioharpes Pribyl and Vaněk (1981). The diagnostic characters are similar to the Harpes diagnosis of Whittington (1959). The distinguishing characters of Helioharpes, namely the sunken alae and irregular radial ridges on the brim and conical glabella as present in $H$. perradiatus Richter and Richter, 1943 and Helioharpes 
radians Richter, 1963 and $H$. transiens Barrande, 1872, are also diagnostic of Harpes. Consequently, Reticuloharpes and Helioharpes are herein considered to be subjective junior synonyms of Harpes.

\section{Species Included}

H. doorcensis Prantl and Pribyl, 1954; H. escoti Bergeron, 1887; H. fornicatus Novák, 1890; H. forojuliensis Gortani, 1909; H. koeneni Wedekind, 1914; H. nymageenensis Fletcher, 1975; H. ormistoni Pribyl and Vanèk, 1986; H. perradiatus Richter and Richter, 1943; H. polaris Maksimova, 1977; H. pyrenaicus Barrios, 1886; $H$. radians Richter, $1963 ; H$. reticulatus Hawle and Corda, 1847; $H$. rouvillei Frech, 1887; H. transiens Barrande, 1872; H. whidbournei Whittington, 1950a; H. sp. nov. (Feist 1977); H. sp. nov. (Feist 1977); H. sp. (Ormiston 1971); H. sp. (Holzapfel 1895); H. sp. (Chlupáč 1969); H. sp. (Weber 1932).

\section{Cladistic analysis}

\section{Outgroups}

The type species of Eoharpes, Bohemoharpes and Lioharpes, have been chosen as outgroups for the Harpes analysis. Bohemoharpes and Lioharpes exhibit significant characteristics atypical of Harpes, such as the large alae, wide (tr.) and vaulted glabella, prominent genal roll and wide brim (sag.). The Middle Devonian Harpes occurs in younger strata than Bohemoharpes and is contemporary with Lioharpes.

Many problematic species have been assigned to Harpes and left there during the many revisions by Prantl, Pribyl and Vanek. Due this practice, the monophyly of Harpes may be questioned on the basis of the addition of species with plesimorphic characteristics commonly attributed to Eoharpes. Therefore, Eoharpes has been added to polarize any primitive characteristics in Harpes to test the monophyly of the genus. $H$. koeneni and $H$. dvorcensis are based on several poor fragmentary crandia and have been omitted from the analysis. The character state data matrix is listed in Table 4.

\section{Characters}

0. Brim shape - elongate. The shape of the brim is influenced by the different conditions of the brim and prolongations. An elongate brim is typically longer (sag.) than it is wide (tr.). The elongate brim is present in Lioharpes.

0 : absent; 1 : present

1. Cephalon shape - semicircular. The semicircular cephalon is typically wider (tr.) than it is long (sag.). Prolongation length does not influence the shape of the cephalon. Eoharpes is semicircular.

0 : absent; 1: present
Table 4 Data matrix for Harpes. '?' indicates missing data

0123456789111111111

012345678

\begin{tabular}{|c|c|}
\hline Eoharpes & 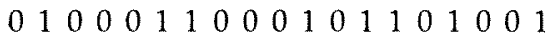 \\
\hline Bohemoharpes & $0001010101000101010 ? ?+0$ \\
\hline Lioharpes & 101100111100100010 \\
\hline H. perradiatus & 100011110001010101111 \\
\hline H. radians & 01011111010 ??????? \\
\hline H. transiens & 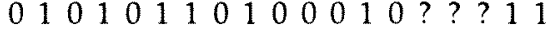 \\
\hline H. frechi & $\begin{array}{llllllllllllllllll}1 & 0 & 0 & 1 & 0 & 1 & 1 & 0 & 1 & 0 & 0 & 0 & 1 & 0 & 1 & 1 & 0 & 1\end{array}$ \\
\hline H. intertextus & $110101000111111 ?$ \\
\hline H. latilimbatus & $11011000010 ?$ \\
\hline H. macrocephalus & 001111010 \\
\hline H. ormistoni & 1110101001000100 \\
\hline H. polaris & $00111010011 ? ? 100$ \\
\hline H. rouvillei & $\begin{array}{llllllllllllll}1 & 0 & 0 & 1 & 1 & 0 & 1 & 0 & 0 & 1 & 1 & 1 & 1 & 0\end{array}$ \\
\hline H. whidbournei & $1011 ? 0 ? 0000 ? 0100$ \\
\hline H. escoti & 10100 \\
\hline H. nymageensis & 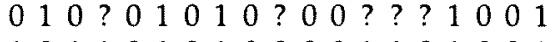 \\
\hline H. reticulatus & $\begin{array}{llllllllllllllllll}1 & 0 & 1 & 1 & 0 & 1 & 0 & 1 & 0 & 0 & 0 & 0 & 1 & 1 & 0 & 1 & 0 & 0\end{array}$ \\
\hline H. socialis & $\begin{array}{llllllllllllllllll}0 & 1 & 0 & 1 & 0 & 1 & 0 & 0 & 0 & 1 & 0 & 0 & 1 & 0 & 1 & 1 & 0 & 0\end{array}$ \\
\hline
\end{tabular}

2. Cephalon shape - pentagonal. The pentagonal shape is influenced by a long brim (sag.), widening (tr.) anteriorly. A pentagonal cephalon is typically wider anteriorly than posteriorly. A cephalon that is wider (tr.) than it is long (sag.) and has an anteriorly expanding cephalon is coded as $0: 0,1: 1,2: 1$. The pentagonal cephalic shape is absent from all outgroups.

0 : absent; 1 : present

3. Anterior boss. There are several states that indicate a developing boss. These are an extension of the axial furrows onto the genal roll and the inflation of the genal roll (sag.) in front of the preglabellar furrow. The anterior boss is present in both Bohemoharpes and Lioharpes, but absent in Eoharpes. 0 : absent; 1: present

4. Conical frontal lobe. The conical frontal lobe is a separate structure to the anterior boss. The conical lobe is an extension of the glabella onto the genal roll. In several specimens the lobe may expand anteriorly as in Helioharpes radians. This condition may be present with an anterior boss or sagittal crest (see character 8 ). The conical lobe is unique to Harpes.

0 : absent; 1 : present

5. Glabella shape - elongate. There are several shapes of the glabella, some unique to one species. All shapes, however, conform to one of two conditions, elongate or triangular. The combination of these two characters yields a bullet shape. An elongate glabella has a relatively consistent length and is 
longer (sag.) than it is wide (tr.). Elongated glabella condition is present in Bohemoharpes.

0 : absent; 1 : present

6. Glabellar shape - sub-triangular. A sub-triangular glabella lacks parallel axial furrows. The glabella is of varying length (sag.), widest (tr.) in the posterior or mid region (anterior to the alae) of the glabella. The sub-triangular glabella is present in Lioharpes. The long triangular shaped glabella is typical of Helioharpes transiens, Harpes intertextus and Eoharpes and is coded as 5: 1, 6: 1 .

0 : absent; 1 : present

7. Girder kink. See character 2 in the Bohemoharpes analysis. The kink is found in Bohemoharpes and Lioharpes, but is absent in Eoharpes.

0 : absent; 1 : present

8. Sagittal crest. The sagittal crest occurs on the whole glabellar midline (sag.) and effaces posteriorly. The crest is absent on the preglabellar furrow and the occipital ring. The crest is present in Lioharpes and other genera with vaulted glabellae.

0 : absent; 1 : present

9. Preglabellar transverse ridge. The preglabellar furrow is deeper in the presence of vaulted ridges. The transverse glabellar ridge is present in Lioharpes.

0 : absent; 1 : present

10. Lateral position of eye. Measured as the lateral position of the midlength of the eye in relation to the abaxial extent of the alar furrow. A score of 10: 1 would indicate that the eye is closer to the axial furrow than the most lateral extent of the alar furrow (positioned closer to the inner margin than to the axial furrow). The position of the eye varies between species of the outgroup, however the type species of Eoharpes and Bohemoharpes commonly have the eye positioned abaxially from the alar furrow.

0 : eye closer to alar furrow; 1 : eye closer to axial furrow

11. Anterolateral position of eye (exsag.). Measured as the position of the midlength of the eye in relation to the preglabellar furrow. The score 11: 1 would indicate that the eye is situated laterally to the preglabellar furrow. The state 11: 1 is rare and does not occur in any of the type species.

0 : eye situated away from preglabellar furrow; 1 : eye situated laterally to preglabellar furrow

12. Alar size. The size of the alae are measured in proportion to $\mathrm{L} 1$, not in proportion to the genal area. The state 12: 1 would indicate that the alae are larger than L1. In the case of vaulted alae, the posterior extent axial furrow is used to distinguish between both organs. Small alae are absent in the outgroup.

0 : smaller than L1; 1: larger than L1.

13. Condition of the alar furrow. The alar furrow may be continuous with the posterior border furrow. This condition forms a wide furrow (tr.) between the ala and posterior border furrow. The alar furrow is continuous with the posterior border furrow in Lioharpes and Bohemoharpes.

0 : absent; 1 : present

14. Sagittal node. The sagittal node occurs on the anterior part of LO. The sagittal node is absent in Lioharpes and Eoharpes.

0 : absent; 1 : present

15. Length of $L O$ (sag.) - long. There are three distinct conditions of LO. It is either longer [15: 1], narrower [16: 1] or the same length [15: 1, 16: 1] as S0 (sag.). A long L0 is common in Lioharpes and Eoharpes.

0 : not longer than S0; 1 : longer than $\mathrm{S} 0$

16. Length of LO (sag.) - narrow. A narrow LO can be associated with a narrow $\mathrm{S} 0$. However a score of 16 : 1 indicates that LO is relatively narrower than SO.

0 : L0 not narrow; 1 : L0 narrow

17. Prolongation longer (exsag.) than cephalic length (sag.). Prolongation length is measured from the base (opposite the posterior border furrow) to the tip. Posterolaterally directed spines are measured as the distance along the external rim. The cephalic length (sag.) is measured from the posterior margin of L0 (sag.) to the anterior border (sag.). Spine length is short in all outgroups.

0 : shorter; 1 : longer

18. Prolongation narrower (exsag.) than prolongation length (sag.). See description above (Character 17).

0 : shorter; 1 : longer

\section{Results and Discussion}

Standard parsimony analysis yielded a completely unresolved consensus tree of 50 trees (length $=46$, ci 41 , ri 57). Three-item analysis found one minimal tree (length $=653$, ci 73, ri 63) (Figure 7), in which species of Helioharpes and Reticuloharpes are scattered throughout Harpes. The basal autapomorphies include the presence of a semicircular shaped brim [1:1], long prolongations [17:1] and eyes situated laterally to the preglabellar furrow [11:1]. There are no basal autapomorphies that define Harpes.

The genus Harpes contains poorly known species that exhibit general characteristics of the Harpetidae, namely the vaulted crandium, inflated glabella and wide perforated brim. Unfortunately Harpes has been used as a taxonomic dumping ground from which better known species have been 


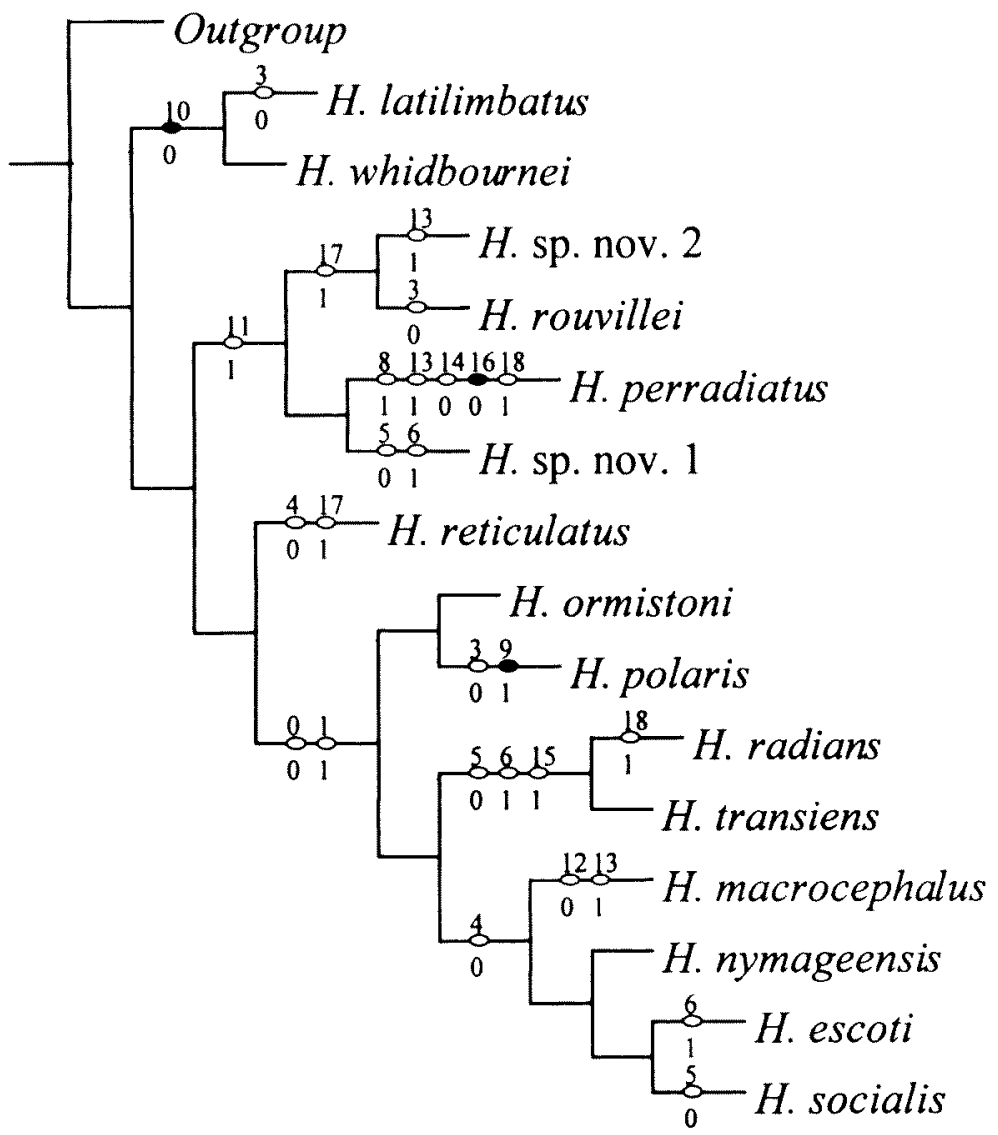

Figure 7 Three-item analysis of Harpes yielded a single minimal tree (length $=653$, ci 73 , ri 63 ).

retrieved to form new genera based only on the characteristics that distinguish them as species, sensu Vaněk (1963) and Pribyl and Vaněk (1981). Harpes, however, has been non-monophyletic since its erection by Goldfuss (1839). At present species of Scotoharpes, Bohemoharpes, Kielania and Hibbertia all have been diagnosed as Harpes at some point. Whether any new genera lie within Harpes is difficult to surmise. Harpes monophyly can only be supported or falsified once new and better specimens and characters are discovered, and a new cladistic analysis performed.

\section{Genus Hibbertia Jones and Woodward, 1898}

Figure 2I

Metaharpes Lamont, 1948a.

Platyharpes Whittington, 1950a: 10; Whittington 1950b: 302.

Paraharpes Whittington, 1950a: 11, Dean 1971: 9; Owen 1981: 32; Owen and Clarkson 1992: 11.

Harpesoides Koroleva, 1978: 216; Pribyl and Vaněk 1986: 24.

Wegelinia Pribyl and Vaněk, 1981: 190.

Thorslundops Přibyl and Vanĕk, 1981: 190.

\section{Type species}

By monotypy, Harpes flanaganni Portlock, $1843=$ Hibbertia orbicularis Jones and Woodward, 1898 from the Caradoc Bardahessiagh Formation of Pomeroy County, Tryone, Northern Ireland.

\section{Emended Diagnosis}

Cephalon semicircular to ovate in outline; brim either flat to concave or strongly convex. Genal roll wide (tr.); transverse preglabellar ridge continuous with eye ridges when present. Glabella strongly vaulted, bullet shaped and lacking ornament. Eyes adaxial to alae; eye ridges present, posterior ocular line effacing on genal roll. L1 triangular shaped; Lo deep and long (sag.), at times continuous with SO. Alae larger than L1 and vaulted, rising steeply toward glabella. Alae ovate, anteriorly directed. Interalar furrow (Figure 1) present. Anterior alar ridge high when present. Coarse pitting on extremities of brim to covering entire brim; large pits on genal area opposite alae. Caeca rare on brim, confined to genal area. Hypostome subquadrangular; anterior wings large. Thorax between 10-25 segments; pygidium small with 5-6 segments. 


\section{Remarks}

Whittington (1950a: 11) noted the close relationship between Paraharpes and Platyharpes, but did not refer to any strong similarities between Hibbertia and Paraharpes. There were no further mentions of any similarities between Hibbertia and Paraharpes in Whittington's (1950b) discussion of the synonymy of Platyharpes and Paraharpes. A later rediagnosis of Hibbertia (Whittington 1959: 418) highlighted the differences from Paraharpes, notably the subcircular outline of the cephalon, narrower genal roll, broader brim, smaller pits on fringe and thorax with fewer than 10 segments. Dean (1971: 5) suggested that both the position of the girder and its extension to the tips of the prolongations are features that distinguish Paraharpes from Hibbertia.

Owen (1981), however, noted only a slight distinction between the genera, highlighting that each diagnosis can "effectively be applied to the type species [Hibbertia flanaganni]" (Owen 1981: 32). Owen (1981) synonymized Metaharpes Lamont, 1948b with Hibbertia (see Armstrong 2000), and Harpesoides Koroleva (1978) with Paraharpes. Pribyl and Vaněk's (1986) diagnosis of Paraharpes points out its close similarity to Hibbertia, differing only "in the oval outline of the cephalon, broader genal roll... narrower flat brim with rather large pits and great number of thoracic segments" (Pribyl and Vanèk 1986: 24), echoing Whittington (1959). Owen and Clarkson (1992) noted that the diagnostic differences between the two genera, as stated by Přibyl and Vaněk (1986), were 'very variable, nondiagnostic characters' and synonymized Paraharpes with Hibbertia (Owen and Clarkson 1982: 11), a move that was endorsed by Lespérance and Weissenberger (1998: 307-308).

In addition to the above synonymies, the two genera Wegelinia and Thorslundops may also be synonymized with Hibbertia. Both genera contain one species each, Harpes wegelini Angelin, 1854 and $H$. dalecarlicus Thorslund, 1930 respectively. Wegelinia was based on a strongly convex brim and lack of functional organs (Pribyl and Vaněk 1981). Thorslundops was based on smaller eye tubercles and a slightly wider brim and narrower prolongations (Pribyl and Vaněk 1981). The diagnoses of both genera do not differ from that of Hibbertia. Consequently, Wegelinia and Thorslundops are herein considered to be junior subjective synonyms of Hibbertia.

\section{Species Included}

Metaharpes amibouei Lamont, 1948b; Harpes anticostiensis Twenhofel, 1928; $H$. balclatchiensis Whittington, 1950a; Hibbertia conistonensis Lespérance and Weissenberger, 1998 [= Paraharpes whittingtoni McNamara, 1979]; Harpes costatus Angelin, 1854; $H$. dalecarlicus Thorslund, 1930; $H$. (Eoharpes) hornei Reed, 1914; Paraharpes inghami

Owen, 1981; Harpesoides (?) karamolensis Koroleva, 1978; H. (?) necopinus Koroleva, 1978; Harpes ottawaensis Billings, 1865; Eoharpes perceensis Kindle, 1945; Paraharpes ruddyi Whittington, 1950a; Harpes similis Nikolaisen, 1965; Paraharpes trippi Whittington, 1950a; Harpes valcourensis Shaw, 1968; $H$. wegelini Angelin, 1854; $H$. whittingtoni Tripp, 1965; H. (?). sp. (Schmidt 1894); H. (?) sp. (Wiman 1908); H. (?) sp. ( Shaw 1968); H. (?). sp. (Bolton 1981); H. (?). sp. (Tripp 1976); H. (?). sp. (Tripp 1979).

\section{Cladisitic analysis}

\section{Outgroup}

The type species Eoharpes primus and Dubhglasina depressus have been chosen as outgroups for the Hibbertia analysis. The outgroups lack the well developed alae, anterior boss, convex brim and long prolongations, but do possess the wide brim, particularly in Dubhglasina, short glabella (sag.), long (tr.) SO, vaulted genal field and genal roll, flat brim and coarse pitting.

Hibbertia karamolensis and $H$. necopinus Koroleva (1978) are described from broken brim and cephalic material. Both are difficult to recognise as species of Hibbertia and are in need of revision. Coding these species is not possible and they are excluded from the analysis. Character states are listed in Table 5.

\section{Characters}

0 . Brim concavity (sag.). Brim concavity is measured sagittally anterior to the genal roll. Flat brims with raised rims may be confused as being concave and should be coded as state 0 .

0 : absent; 1 : present

Table 5 Data matrix for Hibbertia. '?' indicates missing data.

01234567891111

$\begin{array}{llll}0 & 1 & 2 & 3\end{array}$

Eoharpes

Dubhglasina

H. balclatchiensis

$H$. conistonensis

H. costatus

H. dalecarlicus

H. hornei

H. inghami

H. orbicularis

H. ottawaensis

H. perceensis

H. similis

H. trippi

H. valcourensis

H. wegelini

H. whittingtoni
$00000001 ? 0 ? ? 000000$

002001 ? 0 ? 00000

100000000100111011 $10 ? ? ? \quad 0$ ? 10011011

011010111000000

? 02 ? ? ? 0 ? ? 1101010110

$00111100000 ? 1102$

102111001011010

110001000111100

$\begin{array}{llllllllllllll}0 & 1 & 1 & 0 & 1 & 0 & 0 & 1 & 1 & 1 & 1 & 1 & 1 & 1\end{array}$

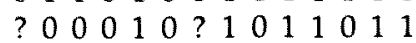

$101 ?$ ? 0000 ? ? 10011

1000100101011010

10000111112 ? 111001 ?

0101100010 ? 010 ?

1100 ? 0 ? ? ? ? 1 ? 1 ? 
1. Brim convexity (sag.). Both brim concavity and convexity can occur at the same time, depending on the convexity of the glabella and genal roll. Brim convexity is measured sagittally anterior to the genal roll.

0 : absent; 1 : present

2. Anterior boss (sag.). The presence of either a ridge extending from the frontal lobe of the glabella to the girder or a large bulbous anterior boss extending at times to the anterior border are different states of character 2. Both these states are derivatives of the extension of the axial furrow pair into the genal roll. The two axial furrows either increase in depth, creating a ridge (2: 1), or curve abaxially to form a boss.

0 : absent; 1 : furrow pair or distinct ridge; 2 : boss

3. Anterior glabellar depression. This may be mistaken for a long (sag.) preglabellar furrow. However, it can be found in association with a transverse preglabellar ridge (see character 4 ).

0 : absent; 1 : present

4. Presence of preglabellar transverse ridge. The ridge is situated between the preglabellar furrow and the girder, and is parallel to the preglabellar furrow between the eye ridges. In several cases the ridge may be continuous with the eye ridges, but there may be little relationship between either homology.

0 : absent; 1 : present.

5. Position of eye (exsag.). Measured as the abaxial extremity of the eye in relation to the most abaxial extent (tr.) of the ala.

0 : adaxial; 1 : abaxial

6. Direction of eye ridge. Only two states occur in Hibbertia. Transversely directed eye ridges may occur early in ontogeny, however fully developed forms possess either state 0 or 1 .

0 : anterolaterally directed; 1 : posterolaterally directed

7. Presence of ocular furrow. The ocular furrow is situated posteriorly to the eye and may be continuous with the axial furrow and efface abaxially to the eye ridge.

0 : absent; 1 : present

8. Condition of interalar furrow. The interalar furrow is parallel and abaxial to the axial furrow. All species of Hibbertia share this character and the two states are prominent. The course of the interalar furrow is consistently parallel to the axial furrows, although in [8: 1] the furrows are adaxial posteriorly and intersect the axial furrows opposite L1.

0 : continuous with posterior border furrows; 1 : continuous with axial furrows.
9. Anterior alar ridge. The alar ridge is situated between an adaxial extension of the palpebral furrow that is continuous with the axial furrow and the anterior extent of the alar furrow. The ridge is parallel to the alar furrow, below the eye to the intersection of the eye ridge and the axial furrow.

0 : absent; 1 : present

10. Coarse pitting and caeca on brim. Coarse pitting and caeca together serve as a possible homologous organ to that of a functional brim. Fine pits or granules have not been associated with a functional brim and herein are treated as an unrelated homology.

0 : absent; 1 : present

11. Caeca on genal area. Caeca and pit structures independent as primary homologies and are interdependant. Caeca present on genal area below the eye and opposite alae are coded as state 1.

0 : absent; 1 : present

12. Coarse pits on genal area. The presence of coarse pits below eye and opposite alae are coded as state 1. Several species may possess a cluster of coarse pits below the eye.

0 : absent; 1 : present

13. Prolongation length (exsag.) versus cephalic length (sag.). Prolongation length is measured from the mid-point of S0 to the most posterior extent of the prolongation spine/tip against cephalic length. Accurate length of the spine is difficult to measure in ovate or circular brims with adaxially directed tips or spines.

0 : less; 1 : equal, 2 : more

\section{Results and discussion}

Standard parsimony analysis resulted in a consensus of 8 trees (length $=33$, ci 48 , ri 61) (characters mapped on to first tree Figure 8) with 6 nodes, one of which is a polytomy of nine taxa (Figure 9). Topologically the consensus provides minimal support for $H$. wegelini, $H$. costatus and $H$. hornei [2: 1], a clade basal to $H$. dalecarlicus and $H$. inghami. Three-item analysis yielded a minimal tree of 16 most parsimonious trees (length $=842$, ci 70 , ri 57) (Figure 10). The minimal tree consists of eight nodes, two of which are polytomies that provide little information regarding relationships of taxa. $H$. costatus and $H$. wegelini are sister taxa within the polytomy and reinforce the synonymy of Wegelinia and Thorslundops within Hibbertia. Hibbertia conistonensis and $H$. balclatchiensis form a sister clade to $H$. perceensis, $H$. ottawaensis, $H$. orbicularis and $H$. whittingtoni.

The three-item and standard parsimony analyses vary greatly in topology, but do contain some similarites. Both analyses, for instance, support the Swedish group of $H$. wegelini and $H$. costatus and a 


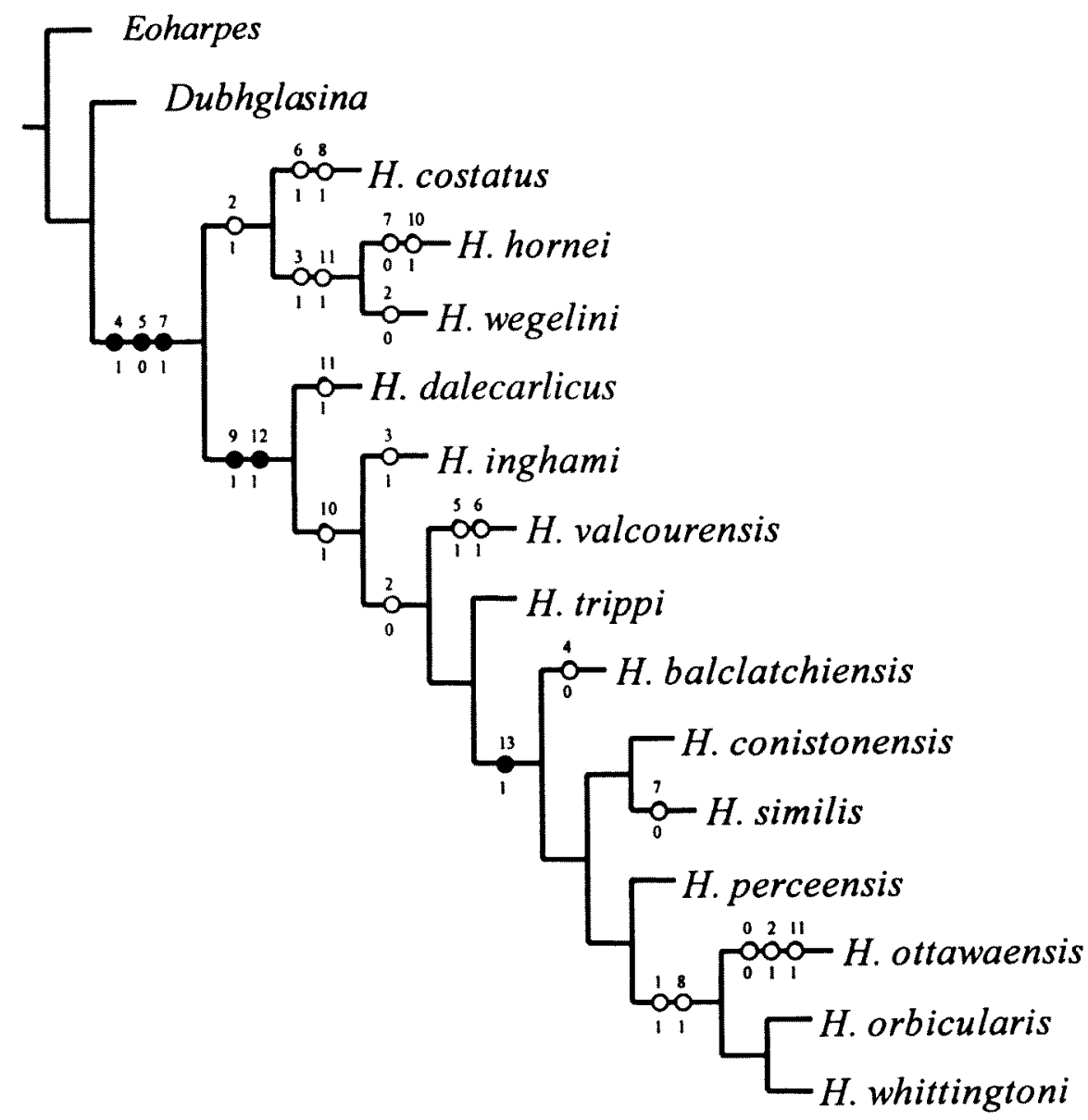

Figure 8 Standard parsimony analysis of Hibbertia. Characters mapped onto first tree from 33 most parsimonious trees (length $=33$, ci 48 , ri 61 ).

monophyletic Hibbertia, consisting of taxa formerly assigned to Platyharpes, Paraharpes, Wegelinia, Thorslundops and Metaharpes. The standard parsimony analysis contains a clade consisting of $H$. costatus, $H$. hornei and $H$. wegelini based on the presence of an extended axial furrow pair on the preglabellar field that is absent in the three-item analysis. The standard parsimony and three-item analyses share similar character-states to support the monophyly of Hibbertia [4: 1, 5: 0, 7: 1]. In the three-item analysis, however, it is interesting to note that Hibbertia is supported by one extra characterstate, namely the presence of an anterior alar ridge that only appears later to support the unresolved clade containing a large portion of the Hibbertia species, with the exception of the aforementioned $H$. costatus, $H$. hornei and $H$. wegelini clade. Differences in the basal node configuration are a result of the implementation of two conceptually different methods.

\section{Genus Kielania Vaněk, 1963}

Kielania (Lowtheria) Prantl and Přibyl, 1981: 189.

\section{Type Species}

Harpes waageni Prantl and Pribyl, 1954 from the

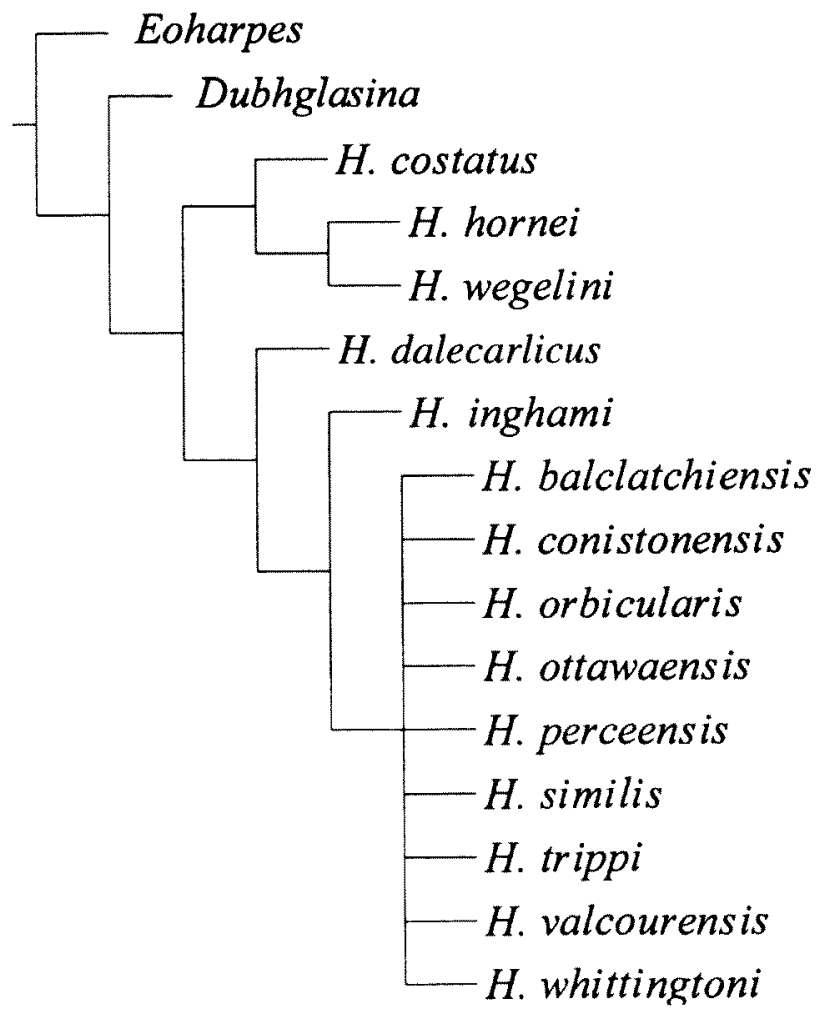

Figure 9 Standard parsimony analysis of Hibbertia found a consensus of 33 most parsimonious trees. 


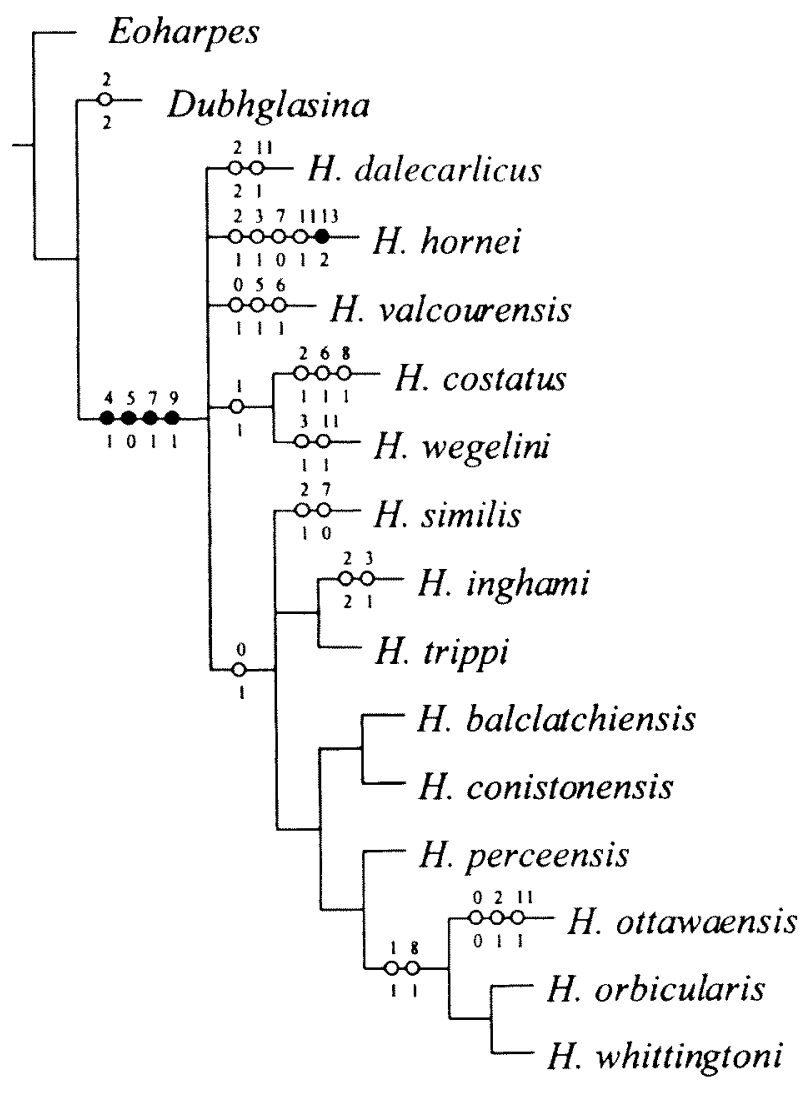

Figure 10 Three-item analysis of Hibbertia found a minimal tree from 16 trees (length $=842, \mathrm{ci}$ 70 , ri 57).

Lower Devonian (Pragian) Dvorce-Prokop Limestone, Prague, Czech Republic.

\section{Emended Diagnosis}

Semi-circular cephalon with vaulted brim. Ovoid glabella with median tubercle (sag.) on frontal lobe. Prolongations short and alae small. Hypostome with convex anterior margin and small posterior wings. Thorax with up to 16 segments; pygidium wide, with $4-6$ axial rings.

\section{Remarks}

Pribyl and Vanek (1986) erected the subgenus Kielania (Lowtheria), on the basis of one species, $K$. (L.) triabsidata. The formalisation of $K$. (Lowtheria) is based purely on diagnostics of a single species rather than a distinct group and is herein synonymised as Kielania.

Ebach and McNamara (in prep.) are describing four new species of Kielania from latest Frasnian sediments associated with extensive reef deposits in the Canning Basin in Western Australia. The descriptions of the new species and a new genus will be accompanied by a cladistic analysis.

\section{Genus Lioharpes Whittington, 1950a}

Figure 2B

Fritchaspis Vanĕk, 1963: 227-8; Prribyl and Vaněk 1986: 20-1.

\section{Type Species}

Harpes venulosus Hawle and Corda, 1847, from the Pragian of Bohemia.

\section{Diagnosis}

Cephalon semicircular; alae large, smooth with deep alar furrows. Caeca and pits well developed on brim and genae. Hypostome pear-shaped with broad, acute anterior wings and narrow lateral borders.

\section{Remarks}

Fritchaspis was erected by Vaněk (1963: 227-8) who considered that it was a direct descendant of Lioharpes, differing in the "more dense and finer perforations" on the brim and preglabellar field, and by a less convex preglabellar field and rounder shape of the frontal lobe, the indistinct eye ridges and in that the "general arch of the cephalon is much smaller". None of the above features can be distinguished as individual characters. Characters such as a less convex preglabellar field and rounder shape of the frontal lobe are variations that are present between species, rather than taxonomic distinctions between two subgenera. The diagnosis of Fritchaspis is synonymous with that of Whittington's (1950a) diagnosis of Lioharpes. Consequently, Fritchaspis is considered to be a subjective junior synonym of Lioharpes.

Vanèk (1963) gave no reason as to why he considered Fritchaspis to be a direct descendant of Lioharpes, other than stating that it "shows the nearest relations to Lioharpes". A later revision of Lioharpes treats Fritchaspis as a subgenus of Lioharpes, "that gave rise to the nominate subgenus Lioharpes (Lioharpes)" (Pribyl and Vanèk 1986: 9). The change of both the status and relationship of Lioharpes (Fritchaspis) is possibly due to the assignment of existing species into Fritchaspis which is positioned lower in the stratigraphic record.

\section{Lioharpes venulosus (Hawle and Corda, 1847)}

Harpes ruderalis Hawle and Corda, 1847: 165. nov. emend. Prantl and Pribyl 1954: 140.

Lioharpes (Lioharpes) venulosus alter Pribyl and Vaněk, 1986: 30.

Lioharpes klukovicensis Vanèk, Vokáč and Hörbinger, 1992: 99.

\section{Discussion}

The differences between the single specimen of $L$. 
klukovicensis and other species of Lioharpes are the "distinctly ovoid glabella lacking carina.... concave brim...pronounced radiating ridges at the genal roll/brim boundary, flat brim and clearly wider glabella at its posterior margin" (Vaněk et al. 1992: 99). This diagnosis is consistent with figured specimens of $L$. venulosus, with the exception of the ovoid glabella that is absent in the specimen of $L$. klukovicensis (Vanèk et al. 1992, pl. 2, fig. 1). Prantl and Pribyl (1954) resurrected L. ruderalis, synonymized into $L$. venulosus by Hawle and Corda (1847), citing a wider cephalon (tr.), cylindrical glabella, fine perforations on brim and the position of the eyes. However, a wider brim is common in slightly deformed specimens, and finer perforations are apparent in external moulds rather than internal moulds. Lioharpes venulosus is perhaps the most common harpetid in the Lochkov Limestones of Bohemia, where most harpetids are found. Morphological variations and deformations used to diagnose $L$. ruderalis above are common in most specimens of L. venulosus.

\section{Lioharpes montagnei (Hawle and Corda, 1847)}

Harpes montagnei Hawle and Corda, 1847: 165.

Harpes perneri Prantl and Přibyl, 1954: 149.

\section{Discussion}

Prantl and Pribyl (1954) believed Kielania dorbignyana (Barrande, 1846) to most closely resemble $L$. perneri, differing only by the smaller eyes, a raised rim, wider alae (tr.) and finer perforations on the cheek-roll and brim. Prantl and Pribyl (1954: 150) suggested that Lioharpes perneri closely resembles Kielania convexus (Hawle and Corda, 1847) and K. novaki Prantl and Pribyl (1954), more so than any species of Lioharpes. The bulbous anterior boss present on the genal roll, long brim (sag.) and strongly tapering prolongations in $L$. perneri, features absent in $K$. dorbignyana are, however, all characteristic of L. montagnei. Harpes pernei is herein considered to be a subjective junior synonym of L. montagnei.

\section{Species included}

Harpes altaicus Weber, 1932; H. bischofi Roemer, 1852; H. crassimargo Novák, 1890; H. hastatus Lütke, 1965; H. montagnei Hawle and Corda, 1847; H. sculptus Hawle and Corda, 1847; L vektori Doubrava, 1991; H. venetus Gortani, 1915; H. sp. (Ancygin 1977); H. sp. (Alberti 1981); H. sp. (Alberti 1969); L. sp. (Rabano and Gutierrez-Marco 1993).

\section{Cladistic analysis}

Outgroups

Hibbertia and Eoharpes are used as outgroups in the Lioharpes analysis. Eoharpes displays plesiomorphic characters of Lioharpes, such as small eyes and alae. Hibbertia shares the ornate brim and palpebral lobes, wide brim, anterior boss, vaulted glabella and large alae. Hibbertia, however, lacks the shallow to sunken alae and inflated genal roll common in most species of Lioharpes. The type species, Hibbertia flanaganni and Eoharpes primus, are selected as outgroups. Lioharpes altaicus, L. bischofi, $L$. venetus and $L$. sp $1-4$ are based on incomplete fragmentary material and have been excluded from the analysis to avoid unnecessary ambiguity.

Character states are listed in Table 6.

\section{Characters}

There are only three species ( $L$. crassimargo, $L$. hastatus, and $L$. venulosus) of the 13 known species of Lioharpes that have fully preserved cephala. Ornament, prolongation length, glabellar shape, position of eyes, direction of eye ridges are similar in these three species. The characters below are the few which distinguish individual species of Lioharpes.

0 . Presence of sagittal ridge. A ridge is continuous from the base of the glabella, opposite L1 to the frontal lobe. Sagittal crest present in Hibbertia and absent in Eoharpes.

0 absent; 1 present.

1. Presence of sunken alae. Sunken alae is defined as being lower than the genal area, as deeply set as the alar furrows. State 0 are either vaulted alae as in Hibbertia or, flat alae that are distinguished by the outline of the alar furrow as in Eoharpes.

0 absent; 1 present.

2. Presence of continuous alar furrow. Defined as an alar furrow continuous with the posterior border furrow. The alar furrow may join the posterior border furrow immediately below the ala.

0 absent; 1 present.

\section{Results and Discussion}

Standard parsimony analysis yielded an unresolved consensus of six trees (length $=9$, ci 100,

Table 6 Data matrix for Lioharpes.

\begin{tabular}{llll}
\hline & 0 & 1 & 2 \\
\hline Eoharpes & 0 & 0 & 0 \\
Hibbertia & 1 & 0 & 1 \\
L. hastatus & 0 & 0 & 1 \\
L. montagnei & 0 & 1 & 1 \\
L. scupltus & 1 & 0 & 0 \\
L. vektori & 0 & 1 & 1 \\
L. venulosus & 1 & 1 & 0 \\
\hline
\end{tabular}




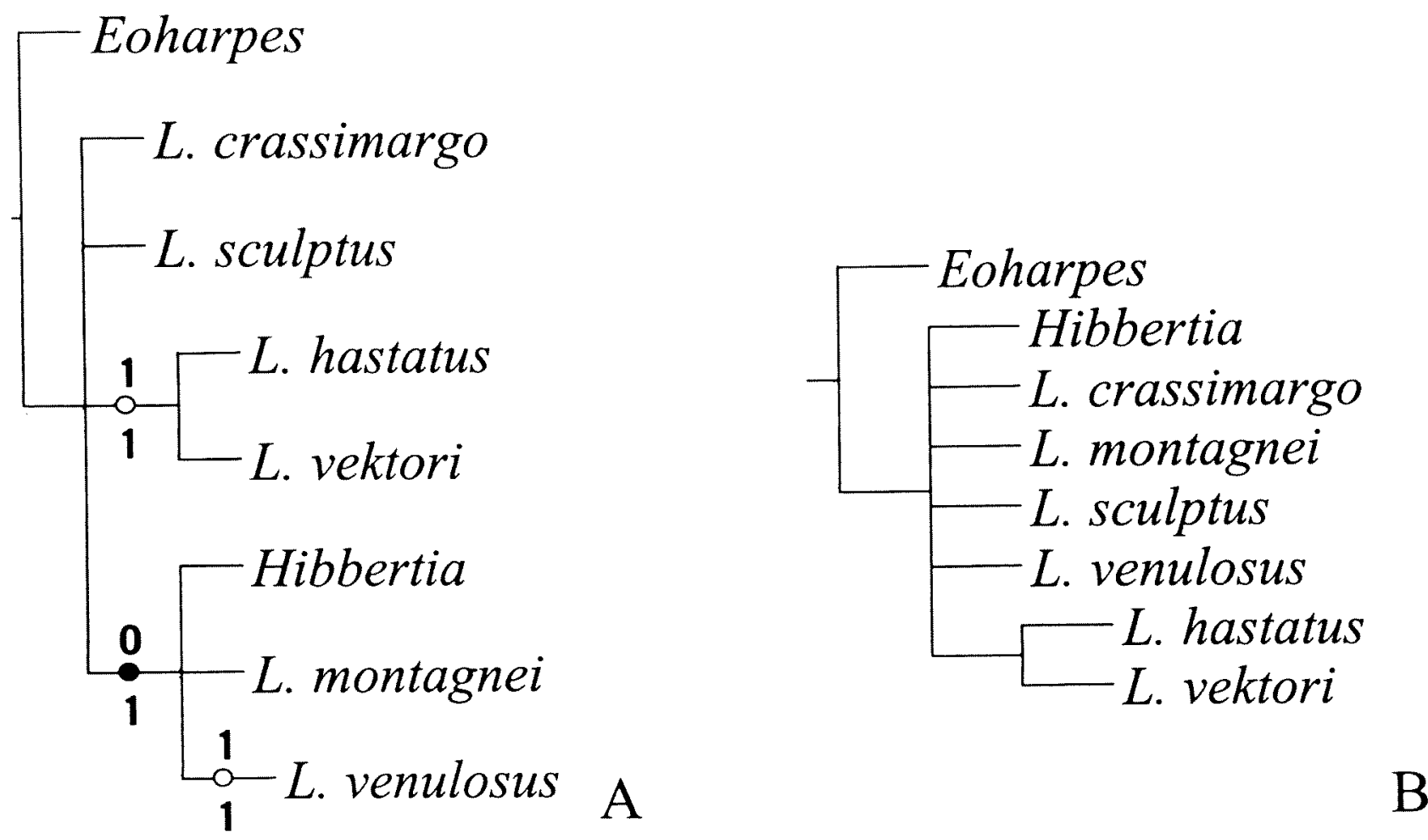

Figure 11 Standard parsimony analysis of Lioharpes found six equally parsimonious trees (length =9, ci 100, ri 100). A. First tree; $B$. consensus.

ri 100) (Figure 11). Three-item analysis found one minimal tree (length $=9$, ci 100, ri 100) (Figure 12) in which the Middle Devonian L. hastatus from the Harz region of Germany, nested with the Lochkovian $L$. venulosus and the Silurian $L$. vektori from Bohemia.

Eight taxa from three areas provide some information on biogeography, namely, Middle Devonian Germany is more closely related to Lochkovian Bohemia than it is to Silurian Bohemia.

The small analysis is included to show the lack of data prevalent in such well known groups as Lioharpes. Despite the lack of morphological charactistics, a cladistic analysis, no matter how small, is still possible.

The standard parsimony analysis provides evidence for a non-monophyletic Lioharpes as Hibbertia is included in the ingroup in each analysis. Lioharpes, however, remains monophyletic in the three-item analysis. The conflict in the results of both analyses is due to the implementation of the methods and the small number of characters (evidence) used. A future analysis run with a greater number of characters and specimens is needed before the paraphyly of Lioharpes can be substantiated.

\section{Genus Scotoharpes Lamont, 1948a Figure 2G}

Aristoharpes Whittington, 1950a: 11.
Selenoharpes Whittington, 1950a: 10.

\section{Type species}

Scotoharpes domina Lamont, 1948a; Llandovery (Lower Silurian), Scotland.

\section{Diagnosis}

Cephalon suboval to subcircular; prolongations almost straight or curving adaxially. Glabella longer than wide, with strong preglabellar and axial furrows. Anterior two pairs of glabellar furrows short and very shallow; posterior pair relatively deep. Preglabellar field short (sag.), flat. Eyes opposite anterior of glabella. Alae low, semicircular. Genal roll with low anterior boss. Brim gently concave or flat; girder prominent, meeting lower internal rim some distance in front of prolongation. Genae and fringe with pits separated by branching caeca. Single rows of larger pits developed against girder and upper and lower rims. Hypostome sagittally elongate. Thorax with at least 17 segments.

\section{Remarks}

The original diagnosis of Scotoharpes by Lamont (1948a: 376-377), which was based on a poor specimen from the Pentland Hills, Scotland, is inadequate. The descriptions of Selenoharpes and Aristoharpes that were later synonymized with Scotoharpes (Norford 1973), serve as better diagnoses for Scotoharpes-type specimens. 


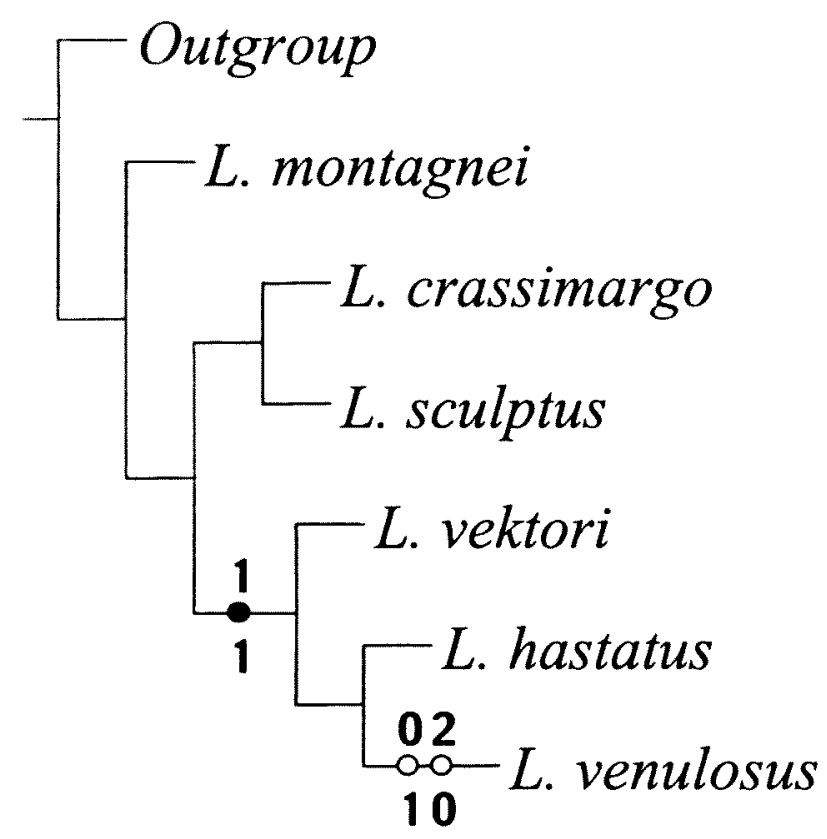

Figure 12 Single minimal tree (length $=9$, ci 100, ri 100) yielded from a three-item analysis of Lioharpes.

\section{Species Included}

Scotoharpes aduncus Fortey, 1980; Harpes cassinensis Whitfield, 1897; $H$. consuetus Billings, 1863; $H$. excavatus Linnarsson, 1875; S. filiarum Dean, 1979; Eoharpes fragilis Raymond, 1925; Harpes granti Billings, 1865; $H$. judex Marr and Nicholson, 1888; H. latior Poulsen, 1934; S. laurei Jell and Stait, 1985; H. tobulatus Chugaeva, 1975; S. loma Lane, 1972; S. molongloensis Chatterton and Campbell, 1980; $H$. pansa Maksimova, 1960; S. planilimbatus Lu, 1975; S. raaschi Norford, 1973; Aristoharpes rotundus Bohlin, 1955; Hibbertia sanctacrucensis Kielan, 1960; Harpes sinensis Grabau, 1925; Selenoharpes singularis Whittington, 1965; Scotoharpes sombrero Owen, 1981; H. spasskii Eichwald, 1840; Aristoharpes taimyricus Balashova, 1959; Selenoharpes tatouyangensis Chang and Fang, 1960; Harpes telleri Weller, 1907; $H$. trinucleoides Etheridge and Mitchell, 1917; Scotoharpes vetustus Zhou and Zhang, 1978; Selenoharpes vitilis Whittington, 1963; Scotoharpes volsellatus Howells, 1982; Aristoharpes willsi Whittington, 1950a; Harpes (Eoharpes) youngi Reed, 1914; S. sp. (Norford 1973); A. (?) sp. (Whittington 1950a); S. (?) sp. (Bordet et al. 1960); H. (?) sp. (Dean 1970); H. (?) sp. (Bates 1968); H. (?) sp. (Kobayashi and Hamada 1972); H. (?) sp. (Owen and Bruton 1980); H. (?) sp. (Thomas 1978); H. (?) sp. (Ingham 1970); H. (?) sp. (Ross 1972); H. (?) sp. (Lane 1979).

\section{Cladisitic analysis}

The cladistic analyses below are restricted to 21 of the 43 known and described species. The majority of species were based on fragmentary material,

insufficient for use in a cladistic analysis. Character states are tabulated in Table 7.

\section{Outgroups}

The type species Eoharpes primus and Bohemoharpes naumanni were chosen as outgroups for the Scotoharpes analysis. All genera share the vaulted glabella, small alae, coarsely pitted rim and prolongations. Scotoharpes consists of a varying degree of morphology that can be attributed to either Eoharpes or Bohemoharpes. The outgroups represent two possible ancestors to Scotoharpes. These characteristics will assist in assessing the monophyly of Scotoharpes.

\section{Characters}

0 . Cephalon shape. Cephalon shape varies considerably in Scotoharpes. Three basic shapes can be determined; squat, rectangular or anteriorly expanded variants. Semicircular cephala do not have strongly adaxially curved prolongations, and ovate brims may have a rectangular shape. Eoharpes and several Bohemoharpes species have a typically semicircular shape. Ovate, circular cephala are possibly derived from a semicircular shape.

0 : Semicircular shaped; 1 : ovate; 2 : circular

1. Brim length. Measured as the length of the brim anteriorly (sag.) against the length opposite eye (lat.). Brim length is even in Eoharpes and varied in

Table 7 Data matrix for Scotoharpes. '?' indicates missing data.

012345678911111111112222222

01234567890123456

Eoharpes

Bohemoharpes

S. cassinensis

S. consuetus

S. domina

S. excavatus

S. filiarum

S. fragilis

S. judex

S. latior

S. laurei

S. loma

S. molongloensis

S. planilimbatus

S. raaschi

S. cf. raaschi

S. singularis

S. sombrero

S. telleri

S. trinucleoides

S. vitilis

S. willsi

S. youngi
010000010100000000012000100 $2000100 ? ? 0000 ? ? 00000 ? 0011 ? 0$ 101101112000000010001101100 $1000010 ? 20000001 ? 00 ? 0 ? 21111$ 000011122010011000112110110 ?? ?1??1?0000011???0?0?????? $0 ? 000 ? 1 ? 20122101 ? 1111000111$ ?100011??0000????????0????? 1100 ???02?0????1001111111?0 ??1000021001110?000000????? 210001002100000100001001111 010 ? ? 1012000011010102100100 100110022000001010112100110 21000 ???2?????????????00111 $0 ? ? 1010 ? 200110001111210 ? 1$ ?? 0111010020010010111121011 ?? 10001000200000 ?0??????21110 $1001111221000101001110211 ? 0$ $1001110 ? ? 00 ? ? ? 100 ? 11 ? 001110$ $1000110220000 ? ? ? 00112111111$ $1110011020100011 ? 1100001110$ $10011 ? ? 2200000 ? 0001121211$ ?? 1001100020000 ?00?????1111?0 


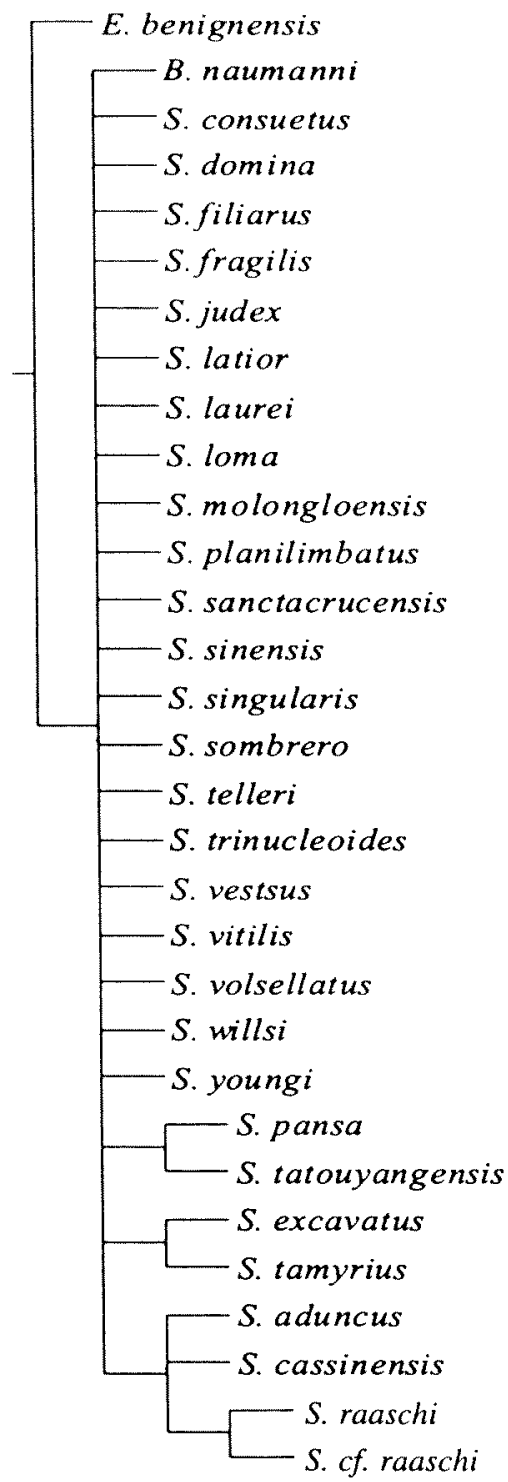

Figure 13 Standard parsimony analysis of Scotoharpes. A strict consensus of 878 most parsimonious trees (length $=120$, ci 27 , ri 56).

Bohemoharpes.

0 : even; 1 : uneven

2. Fringe concavity (sag.). See description in Bohemoharpes character analysis above.

0 : absent; 1 : present

3. Brim slope. Measured sagittally in lateral view. Species that show any sign of anterior slope code as state 1 . Brims with sagittal concavity may show both posterior and anterior slope. Unless there is a distinct anterior slope, concavity is not considered to show presence of slope. Eoharpes has a flat brim with no slope, whereas slope varies greatly in Bohemoharpes.

0 : no slope; 1: gentle slope

4. Presence of axial furrow extension. No known species of Scotoharpes has an anterior boss. However, several species show the anteriorly extended axial furrows onto the genal roll, a possible plesiomorphic state of an anterior boss. Eoharpes lacks axial extensions and/or boss, present in both Bohemoharpes and Scotoharpes.

0 : absent; 1 : present

5. Presence of anterior glabellar depression. The preglabellar furrow is continuous with an anterior glabellar depression. The depression extends sagittally along the genal roll and girder. The depression can be distinguished from the preglabellar field by the transverse preglabellar field.

0 : absent; 1: present.

6. Transverse preglabellar ridge. A difference in depth/concavity of the preglabellar field and genal depression leads to a ridge system that runs parallel to the preglabellar furrow. The transverse preglabellar ridge forms when the genal depression is deeper and/or longer (sag.) than the preglabellar furrow. This character is unique to several species of Scotoharpes.

0 : absent; 1: present

7. Course of inner margin or fringe (sag.). See Character 3 in Bohemoharpes character analysis.

0 : straight; 1 : concave; "W" shaped

8. Course of eye ridge. Unlike Bohemoharpes, eye ridges are distinct in Scotoharpes and occur as three variants. Adaxial ridges only occur between the axial furrow and eye; adaxial ridges either efface along the palpebral margin, or are continuous with the inner margin. Eoharpes and most Bohemoharpes species have an adaxial eye ridge.

0 : adaxial; 1 : effacing abaxially; 2 : continuous with inner margin

9. Glabellar shape. The majority of glabellae in Scotoharpes are bullet-shaped with a variety of sizes, ranging from squat, vaulted to elongate and narrow. Herein angular, strongly tapering glabella are coded as [9: 1].

0 : bullet shaped; 1 : triangular

10. Sagittal crest. This is a distinct ridge that runs along the glabella, that in rare cases may extend on to the genal roll. Extension of the crest may eliminate the possibility of a preglabellar furrow or genal depression. Sagittal crests occur only on elongate, bullet shaped glabella and may act as a strengthening structure. Both outgroups lack a sagittal crest.

0 : absent; 1 : present

11. Condition of S3. S3 and S2 occur in at three separate levels of development. An undeveloped or absent furrow is common in Scotoharpes and both outgroups; adaxially effacing furrows become 
shallower adaxially; medially extended furrows have a constant depth and in the case of S3 are continuous, with S2 abaxially and anterolaterally directed.

0 : not developed/absent; 1 : effacing adaxially; 2 : effacing medially

12. Condition of S2. S2 is laterally directed in state 2 . 0 : not developed/absent; 1 : effacing adaxially; 2 : effacing medially

13. Shape of S1. See Character 6 in Bohemoharpes analysis. The posterolaterally directed S1 may have two shapes: that of a straight line and a curve in the shape of a 'J' 0 : straight; 1 : ' $\mathrm{J}$ '- shaped

14. So depth (sag.). S0 depth sagittally or no continuity in SO depth, occurs with the increase in LO development. Anteriorly or posteriorly directed L0 may change in length (sag.) or become vaulted. This condition is similar to the extension of the glabellar crest and the decrease in depth of the preglabellar furrow in Kielania neogracilis (Richter and Richter 1924). L0 development in Eoharpes and Bohemoharpes is minimal and SO depth generally continuous.

0 : shallow sagittally; 1 : even depth

15. Condition of LO (sag.). Sagittally, LO can be either anteriorly or posteriorly directed. Direction is measured as the direction of the most convex sagittal margin of LO. Convexity of LO is minimal in both outgroups.

0 : posteriorly directed; 1 : anteriorly directed

16. Alar depression. Alar depressions are formed by the anterior widening (tr.) of the alar furrow opposite the axial furrow. The alar depression is usually longer (exsag.) than it is wide (tr.) and does not exceed the depth of the alar furrow. Species without alar depressions have furrows with continuous length. Alar depressions are common in Scotoharpes, but do not occur in genera with smaller unpronounced alae. Alar depressions are absent in both outgroups.

0 : absent; 1 : present

17. Posterior alar depression. The posterolateral lengthening (exsag.) of the alar furrow is known as the posterior alar depression. The posterior alar depression is not as common as the alar depression in Character 16 and may be confused with an alar furrow continuous with the posterior border furrow at its most posterior point (exsag.). The posterior alar depression forms laterally to the ala and extends posterolaterally into the posterior border furrow. The area is usually large, equal in depth to the alar furrow and free of any ornament. Posterior alar depressions are absent in both outgroups. 0 : absent; 1 : present
18. Alar inflation. Alar inflation refers to any relief of the alae. Alae may remain flat, equal in relief to the furrow, either appearing as a faint outline in a large depression or flat surface lateral to the L1. Alar inflation should not be confined to a vaulted ala rising steeply toward $\mathrm{L} 1$.

0 : absent; 1: present

19. Alar direction. Measured as the direction of the posterior alar furrow versus the lateral axis perpendicular to the sagittal. Alae are either parallel or are anterolaterally directed at different angles below 45 degrees. Most alae are asymmetrical and direction is clearly noticeable, however with symmetrical alae, direction is measured as the bilateral axis. Most symmetrical alae are laterally directed.

0 : laterally directed; $1:$ anterolaterally directed

20. Alar size. Alar size is measured in relation to L1, not cranidium size. Hence species with [20: 2] may not actually possess large alae in comparison with other larger species. Measuring ala versus L1 size is justified as both characters are independent, although both are treated as dependent for the purposes of coding.

0 : small; 1 : equal; 2 : large

21. Length of posterior border (exsag.). Measured posteriorly to alae (exsag.) and in relation to SO. For the purpose of coding in cases where So is not preserved, a long posterior border is not usually associated with long (exsag.) posterior border furrows. 0 : narrow; 1 : long

22. Prolongation length (exsag.) versus cephalic length (sag.). Prolongation length is measured sagittally as the distance from $\mathrm{L} 0$ to the level of the prolongation spine/tip, against the anterior border (sag.) to L0 (sag.).

0 : less; 1 : equal, 2: more

23. Internal rim concavity of prolongation. Measured as the concavity of the internal rim of the prolongation excluding the tip/spine.

0 : straight; 1 : convex

24. External rim convexity of prolongation. Measured as the convexity of the external rim of the prolongation, excluding the tip/spine.

0 : straight, 1 : convex.

25. External rim length on prolongation. A thick rim lacks a wide rim furrow and is usually thicker than it is high. Narrow rims usually have a wide concave border. Prolongations possessing spines either have both a thick internal and/or external rim.

0 : narrow; 1 : wide

26. Presence of prolongation spines. Measured as the posterior extent of the external and/or internal rim. 


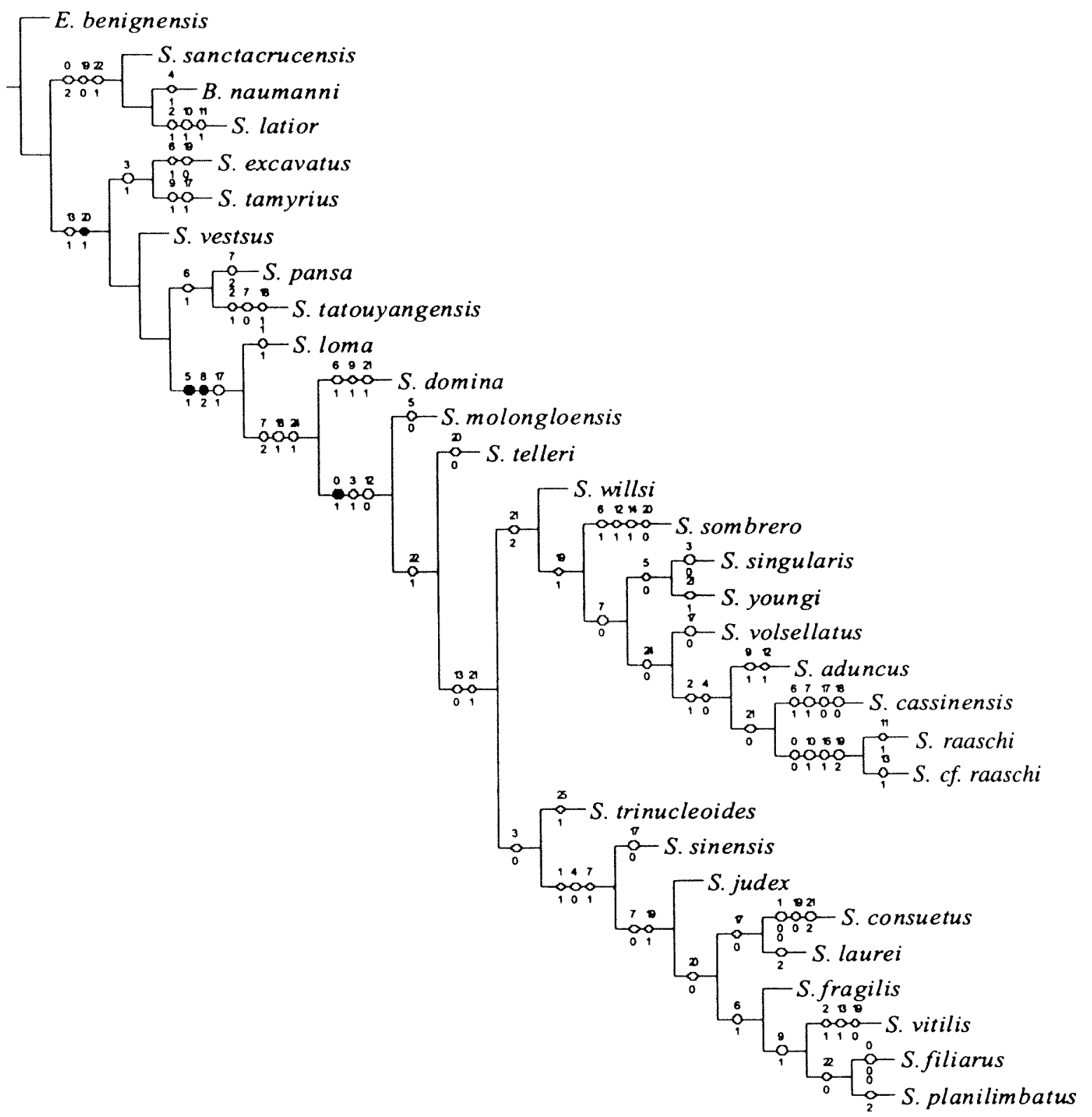

Figure 14 Characters mapped onto first tree of the Scotoharpes standard parsimony analysis (length $=120$, ci 27, ri 56).

The presence or at least one thickened rim margin is necessary for spine formation. Both outgroup taxa lack spines.

0 : absent; 1 : present

\section{Results and Discussion}

Standard parsimony yielded a consensus of 878 most parsimonious trees (length $=120$, ci 27 , ri 56) consisting of four resolved nodes (Figure 13). Characters are mapped on to the first tree in Figure 14. Three-item analysis yielded a minimal cladogram (length $=7995$, ci 67, ri 52) (Figure 15) .

The minimal tree consists of a predominantly Silurian clade containing nine species, of which two are biogeographically and stratigraphically ambiguous, as S. molongloensis is found in the
Middle Silurian of Australia and S. cassinensis in the Lower Ordovician of Vermont, USA. The remaining seven species span from the Ordovician of the United Kingdom to the Silurian of Alaska. This clade is basal to the Sino-AustralianLaurentian clade that includes the type species $S$. domina.

Standard parsimony consensus places Bohemoharpes in the ingroup, whereas the three-item analysis keeps a monophyletic ingroup. These differing results are due to the differences in implementation. Scotoharpes may very well be nonmonophyletic and consist of several monophyletic groups. Scotoharpes, like Harpes, has also been used as a taxonomic dumping ground for taxa or partially preserved taxa. The characteristics 


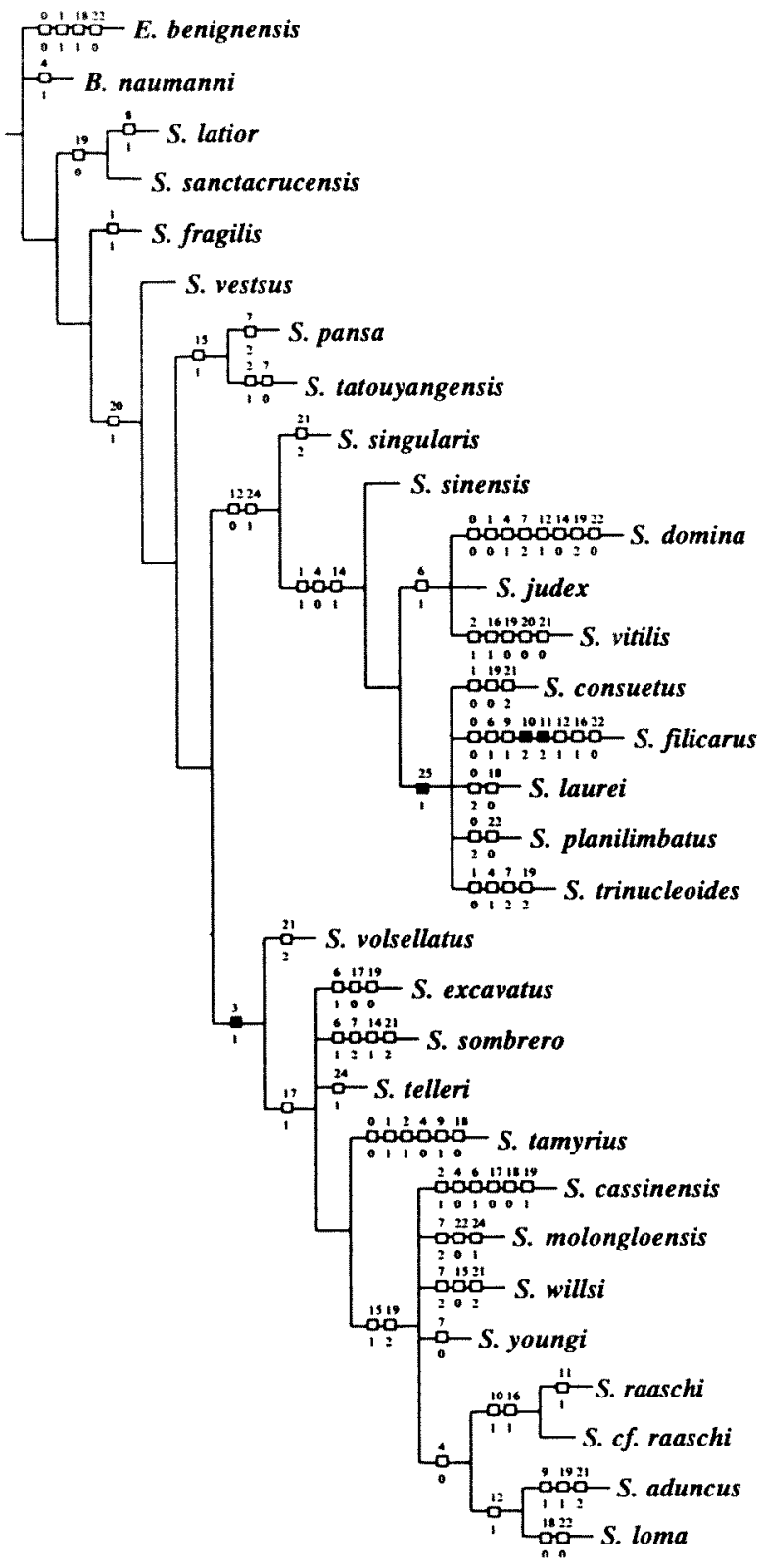

Figure 15 Three-item analysis of Scotoharpes yielded a minimal tree of 216 most parsimonious trees (length $=7995$, ci 67 , ri 52).

attributed to Scotoharpes are so variable that there are no unique Scotoharpes characteristics. This is seen in the similarities that some taxa share with Bohemoharpes and others with Eoharpes. A new cladistic analysis of Scotoharpes is needed. The new analysis should include a larger number of new specimens that are better preserved. Until such an analysis is attempted there can be no certainty over the monophyly of Scotoharpes.

Ordovician species are found both at basal and topographically higher nodes. A stratigraphically mixed clade should not be void if it does not conform to our knowledge of the stratigraphic record. By using stratigraphy to confine our taxa we bias our result. The presence of deeply nested
Ordovician sister taxa in a Silurian clade, or sister taxa of varying ages only highlights the amount of missing data.

\section{NOMEN DUBIA}

Arraphus corniculatus Angelin, 1854; Australoharpes precordilleranus Baldis and Gonzalez, 1986; Harpes antiquatus Billings, 1859; Harpes bucco Bather, 1910; Harpes concavus Thorslund, 1940; Harpes costatus var. actua Weber, 1948; Harpes gotlandium Kegel, 1927; Harpes kylindrorhachis Kobayashi and Hamada, 1972; Harpes minnestoensis Clarke, 1897; Harpes pamiricus Balashova, 1966; Harpes pygmaeus Lütke, 1965; Harpes scanicus Angelin, 1854; Harpes specious Münster, 1840; Trinucleus ellipticus Münster, 1840; Trinucleus issedon Eichwald, 1857; Trinucleus laevis Münster, 1840; Harpes pruniformis Alberti, 1969.

\section{NOMINA NUDUM}

Harpes latilimabtus coll. Krause (1885).

\section{ACKNOWLEDGEMENTS}

We are grateful to David M. Williams and Gregory D. Edgecombe for critically reviewing this manuscript. We are also grateful to Richard Fortey, Raimund Feist, Petr Budil, Jana Slavickova, Thomas Becker, Karsten Weddige, Rod Long and Frau Dorner for their help and assistance. M.C.E. also wishes to thank the Western Australian Museum for support and the University of Melbourne for funding and the Alfred Nicholas Travel Scholarship. We wish to thank Alan Owen for the provision of the photograph of the type specimen of Dubhglasina aldonsensis. Alex Stevens and Alex Baynes are thanked for their editorial assistance.

\section{REFERENCES}

Alberti, H. (1981). Lochkovium/Pragium-Trilobiten aus der Harzgeröder Faltenzone (Harz). Neues Jahrbuch für Geologie und Paläontologie, Abhandlungen 162: 164187.

Alberti, H. (1969). Trilobiten (Harpidae und Odontopleuridae) aus dem Devon des Harzes und des Rheinischen Schiefergebirge (Beitrag II). Geologisches Jahrbuch 87: 361-382.

Ancygin, N.J. (1977). Trilobity, pp. 106-114. In Biostratigrafiya I fauna rannego devona vostochnogo sklona Urala. Ministerstvo geologii RSFSR. Ural'skoe territoral'noe geologicheskoe upravlenie. Nedra, Moscow.

Angelin, N.P. (1854) Palaeontologica Scandinvavia, Pars 1, Iconographia crustaceorum formationis transitionis, Fasciculus II. T. O. Weigel, Lund, pp. 21-92.

Armstrong, H.A., Owen, A.W. and Clarkson, E.N.K. 
(2000). Ordovician limestone clasts in the Lower Old Red Sandstone, Pentland Hills, southern Midland Valley Terrane. Scottish Journal of Geology 36: 33-38.

Balashova, E.A. (1959). Trilobity srednego I verchnego ordovika I nižnego silura vostočnogo Taimyra I ich stratigrafičeskoe značenia. Sbornik statei paleontologiya Biostratigrafiya Institut Arktiki 15: 27-55.

Balashova, E.A. (1966). Trilobity iz ordovikskich I silurijskich otloženij Pamira. Trudy upravu Geologii, Paleontologii Stratigraphii. 2: 191-262.

Baldis, B.A.J. and Gonzalez, S.B. (1986). Australoharpes precordilleranus nov. sp. (Trilobita, Ptychoparida, Harpidae) of the Lower Ordovician of the Sierra de Villicum, San Juan, Argentina. In Simposio; Bioestratigrafa del Paleozoico inferior, San Juan, Argentina 1: 73-79.

Barrande, J. (1846). Notice préliminare sur le systéme Silurien et les Trilobites de Bohême. Bellman, Leipzig, 97 pp.

Barrande, J. (1852). Systéme Silurien du centre de la Bohême. lére partie. Recherches paléontologiques. 1: Trilobites. CW. Medau, Prague and MM. Gottlieb Haase fils, Paris, 935 pp.

Barrande, J. (1872). Systéme Silurien du centre de la Bohême. Ière partie. Recherches paléontologiques, I: Trilobites, Crustacés divers et Poissons (Suppplément). C. W. Medau Prague and M. M. Gottlieb Haase fils, Paris, 647 pp.

Barrios, C.H. (1886). Sur le faune de Hout-de-Ver (HauteGaronne). Annales de Société géologique du Nord 13: 124-144.

Bates, D.E.B. (1968). The Lower Palaeozoic brachiopod and trilobite faunas of Anglesey. Bulletin of the British Museum (Natural History) Geology 16: 125-199.

Bather, F. (1910). Harpes bucco, a new Silurian trilobite from the Carnic Alps. Rivista Italiana di Paleontologia e Stratigraphica 15: 116-120.

Bergeron, J. (1887). Étude paléontologique et stratigraphique des terrains ancient de la Montagne Noire. Bulletin de la Societé Géologiques de France 15: 373-382.

Bergström, J. (1887). Organization, life, and systematics of trilobites. Fossils and Strata 2: 1-69.

Beu, A.G. (1971). Cassididae and Harpidae: Two familygroup homonyms in Mollusca and Arthropoda. Z.N.(S.) 1938. Bulletin of Zoological Nomenclature 28: $564-586$.

Beyrich, E. (1846). Über einige böhmische Trilobiten. Reimer, Berlin.

Billings, E. (1859). On the Crinoidea of the Lower Silurian Rocks of Canada. Geological and Natural History Survey of Canada. 66pp.

Billings, E. (1861-1865). Palaeozoic Fossils vol. 1. Containing descriptions and figures of new or little known species of organic remains from the Silurian rocks. Geological Survey of Canada.

Bohlin, B. (1955). The Lower Ordovician limestones between Ceratopyge Shale and the Platyurus Limestone of Böda Mamn with a description of the microlithology of the limestones by $\mathrm{V}$. Jaanusson. Bulletin of the Geological Institution of the University of Uppsala 25: 111-173.

Bolton, T.E. (1981). Ordovician and Silurian biostratigraphy, Anticosti Island, Québec, pp. 41-59. In Lespérance P.J. (ed.). Field meeting, Anticosti-Gaspé, Québec, 1981. Volume II: Stratigraphy and Paleontology. International Union of Geological Sciences, Subcommission on Silurian Stratigraphy, Ordovician-Silurian boundary Working Group, Département de géologie, Université de Montréal, Montréal.

Bordet, P., Cavel, P. and Pillet, J. (1960). La Faunae silurienne de Pulchauki près de Kathmandu (Himalaya du Népal). Bulletin de la Societé Géologiques de France 7: 3-14.

Bouček, B. (1935). Přispěvek k poznání trilobitö českého Gotlandu (II). Rozpravy Ceske akademiia věd a umèní 34: 1-7.

Bridge, J. (1930). Geology of the Eminence and Cardareva Quadrangles. Missouri Bureau of Geology and Mines 24: 212-222; descriptions of Trilobita credited to Ulrich E. O. pp. 212-222, pls. 19, 21.

Chatterton, B.D.E. and Ludvigsen, R. (1976). Silicified Middle Ordovician trilobites from the South Nahanni River area, District of Mackenzie, Canada. Palaeontographica (A) 154: 1-106.

Chatterton, B.D.E. and Campbell, K.S.W. (1980). Silurian trilobites from near Canberra and some related forms from the Yass Basin. Palaeontographica (A) 167: 77-119.

Chang, W.T. and Fang, C.S. (1960). Class Trilobita of the Ordovician and Silurian Periods of the Chilian Mountains. Geological Gazetteer of the Chilian Mountains 4: 83-148 [in Chinese].

Chavel, J. and Henry, J.L. (1966). Sur la présence du genre Eoharpes Raymond, 1905 (Trilobite) dans l'Ordovicien du Massif armorican. Bulletin de la Societé Géologiques de France 2: 64-65.

Chernohorsky, W.O. (1972). Comment on the homonymous family-group names Cassididae and Harpidae in Mollusca and Arthropoda. Z.N.(S.) 1938. Bulletin of Zoological Nomenclature 29: 108-109.

Chlupáč, I. (1969). The Upper Devonian and Lower Carboniferous trilobites of the Moravian Karst. Sbornîk Geologicky Vědy Rada Péirodní 7: 5-143.

Chugaeva, M.N. (1975). Trilobity pozdnego ordovika severo-vostcka SSSR. Nauka 278: 1-63.

Clarke, J.M. (1897). The lower Silurian trilobites of Minnesota. Minnesota Geological and Natural History Survey 3: 695-759.

Dean, W.T. (1970). Lower Ordovician trilobites from the vicinity of South Catcher Pound, Northeastern Newfoundland. Geological Survey of Ottawa Paper 75: 1-11.

Dean, W.T. (1971). The trilobites of the Chair of Kildare Limestone (Upper Ordovician) of eastern Ireland. Palaeontographical Society [Monograph] 531: 1-25.

Dean, W.T. (1979). Trilobites from the Long Point Group (Ordovician), Port au Poust Peninsula, Southwestern Newfoundland. Geological Survey of Canada Bulletin 290: 1-23.

De Mott, L.L. (1963). Middle Ordovician trilobites from the Upper Mississippi Valley. Unpublished Ph.D. Thesis, Harvard University, Cambridge, Massachusetts.

Dollo, L. (1909). La paléontologie éthologique. Bulletin de la Société belge de géologie 23: 1-377. 
Doubrava, M. (1991). New representatives of the family Harpetidae Hawle and Corda, 1847 (Trilobita) from the Bohemian Silurian. Vèstník Ústředního geologického óstavu 66: 311-314.

Ebach, M.C. and McNamara K.J. (in prep). Late Devonian (Frasnian) harpetid trilobites from the Canning Basin, Western Australia.

Eichwald, E. (1840). Über das silurische Schichtensystem in Estland. St. Petersburg.

Esker, G.C. (1964). New species of trilobites from the Bromide Formation (Pooleville Member) of Oklahoma. Oklahoma Geological Notes 24: 195-209.

Etheridge, R. and Mitchell, J. (1917). The Silurian trilobites of New South Wales, with references to those of other parts of Australia. Part IV. The Calymenidae, Cheiruridae, Harpidae, Bronteidae, etc., with an appendix. Proceedings of the Linnaean Society of New South Wales 42: 480-510.

Fiest, R. (1977). Le Siluro-Devonien du Sud-Est de la Montagne Noire (Herault, France) et ses faunes de trilobites. Unpublished Doctoral Thesis, Université des sciences et Techniques du Languedoc.

Fletcher, H.O. (1975). Trilobites from the Silurian of New South Wales. Records of the Australian Museum 22: 220-233.

Fortey, R.A. (1980). The Ordovician trilobites of Spitzbergen, III. Remaining trilobites of Valhallfonna Formation. Skrifter Norsk Polarinstitutt 171: 1-163.

Fortey, R.A. (1990). Ontogeny, hypostome attachment and trilobite classification. Palaeontology 33: 529-576.

Fortey, R.A. and Chatterton, B.D.E. (1988). Classification of the trilobite suborder Asaphina. Palaeontology 31: 165-222.

Fortey, R.A. and Owens, R.M. (1975). Proetida - a new order of trilobites. Fossils and Strata 4: 237-239.

Frech, F. (1887). Die palaeozoischen bildungen von Cabriéres (Languedoc). Zeitschrift des deutschen Geologishes Gesellschaft 39: 360-489.

Goldfuss, G.A. (1839). Beiträge zur Petrefactenkunde. Verhandlung K. Leopold - Caroline Akademie fur Naturforschung 19: 327-364.

Goloboff, P. (1998). NONA. MS-DOS Program. Version 2.5. Published by author.

Gortani, M. (1909). Contribuzioni allo studio Paleozoico Carnico II. La Fauna a Siluria del Monte Primosio. Memorie della $R$. Accadetia delle scienze dell'Instituto di Bologna 4: 1-44.

Gortani, M. (1915). Contribuzioni allo studio del Paleozoico Carinico V. Fossili eodevonici della base del Capolago (Seekopf). Palaeontographia Italica 21: 117-188.

Grabau, A.W. (1925). A summary of the faunas of the Sintan Shale. Bulletin of the Geological Survey of China 7: 77-85.

Hall, J. (1851). New genera of fossil corals from the report by James Hall, on the palaeontology of New York. American Journal of Science and Arts 11: 398-401.

Harrington, H.J. (1959). Classification. In Moore R.C. (ed.). Treatise of Invertebrate Paleontology, Part O-Arthropoda 1. University of Kansas Press and Geological Society of America, Lawrence, Kansas.
Harrington, H.J. and Leanza, A.F. (1957). Ordovician trilobites of Argentina. Special Publications, Department of Geology, University of Kansas 1: 1-276.

Hawle, J. and Corda, A.J.C. (1847). Prodrom einer Monographie der böhmischen Trilobiten. Abhandlungen der Königlichen Böhmischen Gesellschaft der Wissenschaften 5: 1-176.

Henry, J.L. and Phillipot, A. (1968). Nouvelles découvertes paléontologiques dans $l^{\prime}$ Ordovician moyen d'Ille-et-Vilaine. Comptes Rendus de l'Académie des Sciences, Paris 266: 2187-2189.

Holzapfel, E. (1895). Das obere Mittledevon (Schichten mit Stringocephalus burtini und Maeaneceras terebratum) in Rheinischen Gebirge. Abhandlungen der Preussischen Geologische Landesanstalt 16: 1-459.

Howells, Y. (1982). Silurian trilobites of Scotland. Palaeontographical Society [Monograph] 561: 1-76.

Ingham, J.K. (1970). The Upper Ordovician trilobites from the Cautley and Dent districts of Westmorland and Yorkshire. Palaeontographical Society [Monograph] 124: 1-58.

Jell, P.A. (1978). Trilobite respiration and genal caeca. Alcheringa 2: 251-260.

Jell, P.A. (1985). Tremadoc trilobites of the Digger Island Formation, Waratah Bay, Victoria. Memoirs of the Museum of Victoria 46: 53-88.

Jell, P.A, Stait B. (1985). Tremadoc trilobites from the Florentine Valley Formation, Tim Shea area, Tasmania. Memoirs of the Museum of Victoria 46: 1-33.

Jones, T.R. and Woodward, H. (1898). A monograph of the British Palaeozoic Phyllopoda (Phyllocarida, Packard). Palaeontographical Society [Monograph] 211: 1-31.

Kegel, W. (1927). Über obersilurische Trilobiten aus dem Harz und dem Rheinischen Schiefergebirge. Jahrbuch der Preussischen Geologische Landesanstalt 48: 616-647.

Kindle, C.H. (1945). Two cephalopods and arthropods from the Whitehead Formation. American Journal of Science 243: 159-162.

Kitching, I.J., Forey, P.L., Humphries, C.J. and Williams, D.M. (1998). Cladistics: the theory and practice of parsimony analysis. Second edition. The Systematics Association Publication No. 11, Oxford University Press, Oxford.

Kobayashi, T. and Hamada, T. (1972). Silurian trilobites from the Langkawi Islands Northwest Malaya, with notes on the Dalmanitidae and Raphiophoridae. Geology and Palaeontology of SouthEast Asia 9: 87-134.

Koch, L. and Lemke, U. (1996). Trilobiten aus dem Unteren Tonschiefer (Unteres Llanvirn, Ordovizium) von Kiesbert (Ebbe-Sattel, Rheinisches Schiefergebirge) Teil 2. Geologie und Paläontologie von Westfalen 42: 27-59.

Koroleva, M.N. (1978). New Ordovician Harpidae (Trilobita) of North Kazakhstan. Paleontological Journal 2: 76-80.

Kielan, Z. (1960). Upper Devonian trilobites from Poland and some related forms from Bohemia and Scandinavia. Palaeontolographica polonica 11: 1-198.

Lamont, A. (1948a). Indications of cephalic structure in Trinucleidae and Harpetidae. Nature 162: 376-377. 
Lamont, A. (1948b). Scottish Dragons. Quarry Managers Journal 10: 531-535.

Lane, P.D. (1972). New trilobites from the Silurian of north-west Greenland, with a note on trilobite faunas in pure limestones. Palaeontology 15: 336-364.

Lane, P.D. (1979). Llandovery trilobites from Washington Land, North Greenland. Grønlands Geologiske Undersøgelse Bulletin 530: 1-37.

Lespérance, P.J. and Weissenberger, J.A.W. (1998). Trilobites of the Pabos Formation (Ashgillian, Upper Ordovician) Percé area, Québec. Journal of Paleontology 72: 303-316.

Lindström, G. (1885). Förtecking på Gotlands siluriska crustacéer. Öfversigt af Kongliga Vetenskaps- Akademiens Förhandlingar 42: 37-99.

Linnarsson, G. (1875). Öfversigt af Nerikes Øfvergnsbildningar. Öfversigt af Kongliga VetenskapsAkademiens Förhandlingar 32: 3-48.

Ludvigsen, R. (1982). Upper Cambrian and Lower Ordovician trilobite biostratigraphy of the Rabbitkettle Formation, western District of Mackenzie. Contributions. Life Science Division, Royal Ontario Museum 134: 1-188.

Lu, Y.H. (1975). Ordovician trilobite faunas of central and southwestern China. Palaeontologia sinica, New Series 11: $1-463$.

Lütke, F. (1965). Zur kenntnis herzynischer Trilobiten aus dem unter- und mittledevon des Harzes. Palaeontographica (A) 124: 151-236.

Maksimova, Z.A. (1960). New Middle Palaeozoic trilobites of central Kazakhstan, Rudny Altae and the Arctic. In New species of prehistoric plants and invertebrates of the USSR. Markovsky BP. (ed.) Trudy Vsesoyuznogo nauchno-issledovatelskogo Geologischeskogo Instituta, 2: 256-280.

Maksimova, Z.A, (1977). Devonian Trilobites from Novaya Zemlya and other regions of the Soviet Arctic. Ezhegodnik Vsesoyuznogo Paleontogischeskogo Obshchchestva 20: 140-181.

Marr, J.E. and Nicholson, H.A. (1888). The Stockdale Shales. Quarterly Journal of the Geological Society, London 44: 654-732.

M'Coy, F. (1851). On some Cambro-Silurian fossils. Annals and Magazine of Natural History 8: 387-409.

M'Coy, F. (1852). In Sedgwick, A and M'Coy, F. 1851-1855. A synopsis of the classification of the British Palæozoic rocks by Adam Sedgwick. With a systematic description of the British Palæozoic fossils in the Geological Museum of the University of Cambridge by Frederick McCoy. London, J.W. Parker and Son.

McNamara, K.J. 1979. Trilobites from the Coniston Limstone Group (Ashgill Series) of the Lake District, England. Palaeontology 22: 53-92.

Miller, J. (1972). Aspects of biology and palaeoecology of trilobites. Unpublished Ph.D. Thesis, University of Manchester, United Kingdom.

Morris, S.F. (1988). A review of British trilobites including a synoptic revision of Salter's monograph. Palaeontographical Society [Monograph] 140, $316 \mathrm{pp}$.

Münster, G. (1840). Die Versteinerungen des Über gangskalkes mit Clymenien und Orthocerationen von
Oberfranken. Ein Beitrag zur Petrefactonkunde, III 7: 33121.

Nelson, G. and Ladiges, P.Y. (1995). TAX: MS-DOS programs for cladistics, version 3.3. New York and Melbourne.

Nelson, G. and Platnick, N. I. (1991). Three-taxon statements: A more precise use of parsimony? Cladistics 7, 351-366.

Nikolaisen, F. (1965). The Middle Ordovician of the Oslo region, Norway. Rare trilobites of the families Olenidae, Harpidae, Itoyphoridae and Cheiruridae. Norsk geologisk Tiddskrift 145: 231-348.

Nixon, K.C. (1999). Winclada version 0.9 for Windows. Published by the author.

Norford, B.S. (1973). Lower Silurian species of the trilobite Scotoharpes from Canada and Northwestern Greenland. Geological Survey of Canada Bulletin 222: 9-33.

Novák, O. (1884). Studien an Hypostomen böhmischer Trilobiten, II. Sitzungsberichte der böhmischen Gesellscaften der Wissenscaften von Mathematik und Natur Prague 20 pp.

Novák, O. (1885). Studien an Hypostomen böhmischer Trilobiten, III. Sitzungsberichte der böhmischen Gesellscaften der Wissenscaften von Mathematik und Natur, Prague 8 pp.

Novák, O. (1890).Vergleichende Studien an einigen Trilobiten aus dem Hercyn von Bicken, Wildungen, Greifenstein und Böhmen. Pälaeontologishes Abhandlungen, Neu Folge 1: 95-137.

Opinion, 1436 (1987). Harpetidae Hawle and Corda, 1847 (Trilobita) and Harpidae Bronn, 1849 (Mollusca, Gastropoda): a ruling to remove the homonymy. Bulletin of Zoological Nomenclature 44: 137-138.

Ormiston, A.R. (1971). A new Devonian harpid trilobite species from Lowther Island, district of Franklin. Geological Survey of Canada Bulletin 197: 23-26.

Ormiston, A.R. (1973). A new Devonian harpid trilobite species from Lowther Island, District of Franklin. Geological Survey of Canada Bulletin 222: 23-27.

Owen, A.W. (1981). The Ashgill trilobites of the Oslo region, Norway. Palaeontographica (A) 175: 1-88.

Owen, A.W. and Bruton, D.L. (1980). Late Caradoc-early Ashgill trilobites of the central Oslo Region, Norway. Palaeontological Contributions of the University of Oslo 245: 1-42.

Owen, A.W. and Clarkson, E.N.K. (1992). Trilobites from Kilbucho and Wallace's Cast and the location of the Northern Belt of the Southern Uplands during the Late Ordovician. Scottish Journal of Geology 28: 3-17.

Owen, A.W., Harper, D.A.T. and Clarkson, E.N.K. (1996). The trilobites and brachiopods of the Wrae Limestone, an Ordovician limestone conglomerate in the Southern Uplands. Scottish Journal of Geology 32: 133-149.

Peng, S. (1984). Cambrian-Ordovician boundary in the Cili-Tapyuan border area, northwestern Hunan, with descriptions of the relative trilobites. $285-405 \mathrm{pp}$. In Nanjing Institute of Geology and Palaeontology, Academia Sinica. Stratigraphy and Palaeontology of systemic boundaries in China. Cambrian-Ordovician boundary, 1. Anhui Science and Technology Publishing House, Heifel [in Chinese]. 
Peng, S. (1990). Tremadoc stratigraphy and trilobite faunas of northwestern Hunan (China). Trilobites from the Panjiazui Formation and the Madaoyu Formation in Jiangnan Slope Belt. Beringeria 2: 55-171.

Petrunina, Z.E. (1966). Trilobity I biostratigrafia tremadoka zapadnoj casti sajanoaltajskij gornoj oblasti. Nauk Kazachskoj SSSR. Alma-Ata 3-30.

Portlock, J.E. (1843). Report on the geology of the county of Londonderry and parts of Tyrone and Fermanagh. Her Majesty's Stationary Office, Dublin, 784 pp.

Poulsen, C. (1934). The Silurian faunas of North Greenland. I. The fauna of the Cape Schuchert Formation. Meddelelser Om Grønland 72: 1-46.

Prantl, F. and Pribyl, A. (1954). On the Bohemian representatives of the family Harpedidiae (Hawle and Corda). Rozpravy ústrednúho ústavu geologickiho 18: 121-180.

Přibyl, A. and Vaněk, J. (1981). Preliminary report on some new trilobites of the family Harpetidae Hawle et Corda. Casopis pro mineralogii a geologii 26: 187-194.

Pribyl, A. and Vanèk, J. (1986). A study of the morphology and phylogeny of the family Harpetidae Hawle and Corda, 1874 (Trilobita). Sbornk národního muzea v praze 152: 1-73.

Rabano, I. and Gutierrez-Marco, J.C. (1993). Upper Silurian trilobites from the west Asturian-Leonese zone (NW Spain). Geobios 26: 361-376.

Raymond, P.E. (1905). Notes on the names Amphion, Harpina and Platymetopus. American Journal of Science 7: $377-378$.

Raymond, P.E. (1925). Some trilobites of the Lower Middle Ordovician of eastern North America. Bulletin of the Museum of Comparative Zoology of Harvard College 67: 3-180.

Reed, F.R.C. (1914). Supplementary memoir on new Ordovician and Silurian fossils from the Northern Shan States. Palaeontographica Indica 6: 1-122.

Rheder, H.A. (1972). Comment on proposal to remove homonymy of Cassididae and Harpidae in Mollusca and Arthropoda. Z.N.(S.) 1936. Bulletin of Zoological Nomenclature 29: 2.

Rheder, H.A. (1973). Comment on the proposals concerning family names Cassididae and Harpidae in Mollusca and Arthropoda. Z.N.(S.) 1936. Bulletin of Zoological Nomenclature 30: 3.

Richter, R. 1863. Der Kuln in Thüringen. Abdruck aus dem Zeitschriften der deutschen geologischen Gesellschaft, pp. 155-172.

Richter, R. (1920). Beiträge zur Kenntnis devonisher Trilobiten III: Über die Organisation von Harpes, einen Sonderfall unter Crustaceen. Sonderabdruck aus dem Abhandlungen der Senckenbergischen Naturforschenden Gesellschaft 31: 1-218.

Richter, R. and Richter E. (1943). Studien im Paläozoikum der Mittelmeer-Länder. 4a. Trilobiten aus dem Devon von Marokko. Senckenbergiana 26: 116-199.

Roemer, F.A. (1852). Beiträge zur geologishen Kenntnis des nordwestlichen Harzgebirges (Abt. 2). Palaeontographica (A) 3: 67-111.

Romano, M. (1975). Harpid trilobites from the Ordovician of North Portugal. Comunicações Service Geológico Portugal 59: 27-36.
Romano, M. and Henry, J.L. (1982). The trilobite genus Eoharpes from the Ordovician of Brittany and Portugal. Palaeontology 25: 623-633.

Ross, R. J. Jr. (1972). Fossils from the Ordovician bioherm at Meiklejohn Peak, Nevada. US Geological Survey Professional Paper 685: 1-38.

Rouault, M. (1847). Extrait du Mémoire sur les Trilobites du Département d'Ille-et-Villaine. Bulletin de la Societé géologiques de France 4: 309-328.

Salter, J.W. (1864). A monograph of the British trilobites from the Cambrian, Silurian and Devonian formations. Palaeontographical Society [Monograph] 1: $1-180$.

Schmidt, F. (1894). Revision der ostbaltischen silurischen Trilobiten. Mémoire de l'Acadamie imperial des Sciences de St. Pétersbourg 7: 1-93.

Scotland, R.W. and Pennington, R.T. (2000). Homology and systematics: coding characters for phylogenetic analysis. Francis and Taylor, London.

Shaw, F.C. (1968). Early Middle Ordovician Chazy trilobites of New York. New York State Museum and Science Service 17: 1-114.

Sheng X. (1974b). Ordovician trilobites from western Yunnan and its stratigraphical significance. In Subdivision and correlation of the Ordovician System in China 59-95. Geological Publishing House, Beijing.

Sinclair, G.W. (1947). Two examples of injury in Ordovician trilobites. American Journal of Science 245: 250-257.

Staff, H. and Reck, H. (1911). Über die Lebensweise der Trilobiten. Eine entwicklungsmechanishe Studie. Sitzungsberichte die Gesellschaft naturforschender Fruende zu Berlin p.130-146 pp.

Sternberg, G. von (1833). Rede von Kaspar Grafenn von Sternberg, Beilage 3. Verhandlungen der Gesellschaft des Vaterländischen Museum in Böhmen 45-56 pp.

Stubblefield, C.J. (1936). Cephalic sutures and their bearing on current classification of trilobites. Biological Reviews 11: 407-440.

Swinnerton, H.H. (1915). Suggestions for a revised classification of trilobites. Geological Magazine 6: 487$496,538-545$.

Thomas, A.T. (1978). British Wenlock trilobites. Palaeontographical Society [Monograph] 552: 1-56.

Thorslund, P. (1930). Über einige neue Trilobiten aus dem älterten Leptaena-Kalk Dalekarliens. Bulletin of the Geological Institution of the University of Uppsala 22: 299-303.

Thorslund, P. (1940). On the Chasmops Series of Jemtland and Södermanland (Tvären). Sveriges Geologiska Undersökning. Avhhandlingar och Uppsaster 436: 1-191.

Tripp, R.P. (1965). Trilobites from the Albany Division (Ordovician) of the Girvan district, Ayrshire. Palaeontology 8: 577-603.

Tripp, R.P. (1976). Trilobites from the basal superstes Mudstone (Ordovician) at Aldons Quarry, near Girvan, Ayrshire. Transactions of the Royal Society of Edinburgh: Earth Sciences 69: 269-423.

Tripp, R.P. (1979). Trilobites from the Ordovician Auchensoul and Stinchar Limestones of the Girvan District, Strathclyde. Palaeontology 22: 339-361. 
Tripp, R.P., Zhou, Z. and Pan, Z. (1989). Trilobites from the Upper Ordovician Tangtou Formation, Jiangsu Province, China. Transactions of the Royal Society of Edinburgh: Earth Sciences 80: 25-68.

Twenhofel, W.H. (1928 [1927]). Geology of Anticosti Island. Geological Survey of Canada, Memoir 154: 1-481.

Vaněk, J. (1963). Nové rody čeledi Harpidae Hawle et Corda, 1847 (Trilobita). Casopis Nărodnino Muzea Oddil (Prirodevěý) 132: 226-229.

Vaněk, J., Vokáč, V. and Hörbinger, F. (1992). New trilobites from the Silurian and Devonian in the Prague Basin (Central Bohemia). Věstnik Ústředního geologického ústavu 67: 97-108.

Walch, J.E.I. (1771). Die Naturgescichte der Versteinerungen, zur Erläuterung der Knorrischen Sammlung von Merkwürdigkeiten der Natur, Volume 4, part 3. Paul Jonathan Felstecker, Nürnberg, 184 pp.

Weber, W.N. (1932). Trilobity Turkestana. Trudy Geologicheskogo Komiteta 178: 1-157.

Weber, W.N. (1948). Trilobity silurijskich otloženij SSSR. 1. Nižnesilurijskie trilobity. Monographs of the Palaeontology of the USSR, Ministry of Geology, Moscow 69: 1-113.

Wedekind, R. (1914). Paläontologishe beiträge zur geologie des kellerwaldes. Abhandlungen der Preussischen Geologische Landesanstalt 69: 1-84.

Weller, S. (1907). The paleontology of the Niagaran Limestone in the Chicago area. The Trilobita. Bulletin of the Chicago Academy of Sciences 4: 163-281.

Whitfield, R.P. (1897). Descriptions of new species of Silurian fossils from near Fort Cassin and elsewhere on Lake Champlain. Bulletin of the American Museum of Natural History Article 11: 177-184.

Whittington, H.B. (1949). Redescription of the trilobite Eoharpes Raymond 1905. Quarterly Journal of the Geological Society 54: 221-228.

Whittington, H.B. (1950a). British trilobites of the family Harpidae. Palaeontographical Society [Monograph], $55 \mathrm{pp}$.

Whittington, H.B. (1950b). Platyharpes Whittington, 1950, a synonym of Hibbertia Jones and Woodward, 1898. Geological Magazine 87: 302.
Whittington, H.B. (1950c). Swedish Lower Ordovician Harpidae and the genus Harpides. Geologiska Föreningens I Stockholm Förhandlingar 72: 301-306.

Whittington, H.B. (1954). Ordovician trilobites from Silliman's Fossil Mount. In A.K. Miller, W. Youngquist and C. Collinson (eds) Ordovician cephalopod fauna of Baffin Island. Memoirs Geological Survey of America 62: 119-149.

Whittington, H.B. (1959). Description of the Suborder Harpina. In Moore R.C. (ed.). Treatise of Invertebrate Paleontology, Part O - Arthropoda 1. University of Kansas Press and Geological Society of America, Lawrence, Kansas.

Whittington, H.B. (1963). Middle Ordovician trilobites from the Lower Head, western Newfoundland. Bulletin of the Museum of Comparative Zoology, Harvard College 129: 1-118.

Whittington, H.B. (1965). Trilobites of the Ordovician Table Head Formation, western Newfoundland. Bulletin of the Museum of Comparative Zoology, Harvard College 132: 275-442.

Whittington, H.B. (1997). The trilobite body. In Kaesler R.L. (ed.). The Treatise on Invertebrate Paleontology, Part O, Arthropoda 1, Trilobita, Revised. The Geological Society of America and University of Kansas Boulder, Colorado and Lawrence, Kansas.

Williams, D.M. (1996). Fossil species of the diatom genus Tetracyclus (Bacillariophyta, 'ellipticus' species group): morphology, interrelationships and the relevance of ontogeny. Philosophical Transactions of the Royal Society of London 351: 1759-1782.

Wiman, C. (1908). Studien über das Nordbaltische Silurgebiet, II. Bulletin of the Geological Institution of the University of Uppsala 8: 1906-1907.

Zhou, Z. and Zhang, J. (1978). Cambro-Ordovician boundary of the Tangshan area with descriptions of the related trilobite fauna. Acta Palaeontologica Sinica 17: 1-12.

Manuscript received 5 November 2001; accepted 24 May 2002 